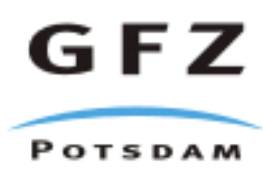

Originally published as:

Beurlen, H., Da Silva, M. R. R., Thomas, R., Soares, D. R., Olivier, P. (2008): Nb-Ta-(Ti-Sn) oxide mineral chemistry as tracer of rare-element granitic pegmatite fractionation in the Borborema Province, Northeastern Brazil. - Mineralium Deposita, 43, 2, 207-228,

DOI: $10.1007 / \mathrm{s} 00126-007-0152-4$. 


\title{
Nb-Ta-(Ti-Sn) oxide mineral chemistry as tracer of rare- element granitic pegmatite fractionation in the Borborema Province, Northeastern Brazil
}

\author{
Hartmut Beurlen • Marcelo R. R. Da Silva • \\ Rainer Thomas $\cdot$ Dwight R. Soares • Patrick Olivier
}

Received: 30 November 2005 / Accepted: 10 June 2007

(C) Springer-Verlag 2007

\begin{abstract}
The Borborema Pegmatitic Province (BPP), northeastern Brazil, is historically important for tantalum mining and also famous for top-quality specimens of exotic $\mathrm{Nb}-\mathrm{Ta}$ oxides and, more recently, for the production of gem quality, turquoise blue, 'Paraíba Elbaite.' With more than 750 registered mineralized rare-element granitic pegmatites, the BPP extends over an area of about 75 by $150 \mathrm{~km}$ in the eastern part of the Neoproterozoic Seridó Belt. The Late Cambrian pegmatites are mostly hosted by a sequence of Neoproterozoic cordierite-sillimanite biotite schists of the Seridó Formation and quartzites and metaconglomerates of the Equador Formation. The trace-element ratios in feldspar and micas allow to classify most pegmatites as belonging to the beryl-columbite phosphate subtype. Electron microprobe analyses (EMPA) of columbite, tapiolite, niobiantantalian rutile, ixiolite and wodginite group minerals from 28 pegmatites in the BPP are used to evaluate the
\end{abstract}

Editorial handling: S. Hagemann

H. Beurlen $(\bowtie) \cdot$ D. R. Soares

Programa de Pós-Graduação em Geociências, Universidade

Federal de Pernambuco (UFPE),

Rua Acadêmico Hélio Ramos s.n., Cidade Universitária,

50740-530 Recife, PE, Brazil

e-mail: beurlen@terra.com.br

M. R. R. Da Silva • P. Olivier

Departamento de Geologia

Universidade Federal de Pernambuco (UFPE),

Rua Acadêmico Hélio Ramos s.n., Cidade Universitária, 50740-530 Recife, PE, Brazil

M. R. R. Da Silva

e-mail: marcelor@ufpe.br

R. Thomas

GeoForschungsZentrum Potsdam,

Telegrafenberg,

14473 Potsdam, Germany effectiveness of $\mathrm{Nb}-\mathrm{Ta}$ oxide chemistry as a possible exploration tool, to trace the degree of pegmatite fractionation and to classify the pegmatites. The columbite group mineral composition allows to establish a compositional trend from manganoan ferrocolumbite to manganocolumbite and on to manganotantalite. This trend is typical of complex spodumene- and/or lepidolite-subtype pegmatites. It clearly contrasts with another trend, from ferrocolumbite through ferrotantalite to ferrowodginite and ferrotapiolite compositions, typical of pegmatites of the beryl-columbite phosphate subtype. Large scatter and anomalous trends in zoned crystals partially overlap and conceal the two main evolution patterns. This indicates that a large representative data set of heavy mineral concentrate samples, collected systematically along cross-sections, would be necessary to predict the metallogenetic potential of individual pegmatites. Other mineral species, e.g. garnets and/or tourmaline, with a more regular distribution than $\mathrm{Nb}-\mathrm{Ta}$ oxides, would be more appropriate and less expensive for routine exploration purposes. The currently available $\mathrm{Nb}-\mathrm{Ta}$ oxide chemistry data suggest the potential for highly fractionated $\mathrm{Ta}-\mathrm{Li}-\mathrm{Cs}$ pegmatites in the BPP, so far undiscovered, and encourages further, more detailed research.

Keywords $\mathrm{Nb}-\mathrm{Ta}-\mathrm{Ti}-\mathrm{Sn}$ oxides $\cdot$ Rare-element granitic pegmatites $\cdot$ Borborema Pegmatitic Province $\cdot$ Brazil

\section{Introduction}

Niobium-Ta-(Ti-Sn) oxide mineral chemistry data, based mainly on minerals of the columbite, tapiolite and ixiolite groups, are commonly used in pegmatite provinces worldwide as tracers of pegmatite magma fractionation, for the prediction of the metallogenetic potential or petrological 
classification purposes (Černý and Ercit 1985, 1989; Tindle and Breaks 2000; Černý 1989b, 1992, 1998). This kind of study may gain in importance because the potential for high grade $\mathrm{Ta}, \mathrm{Li}$ and $\mathrm{Cs}$ ore increases with the degree of pegmatite magma fractionation.

The Borborema Pegmatitic Province (BPP) in northeastern Brazil is known since the beginning of the last century, when it was exploited for mica during World War I. It became well known during World War II as one of the world's most important Ta-Be producers, and during 19401950 for the production of beautiful specimens (Pough 1945; Johnston 1945; Rolff 1946) of 'exotic' tantalates, being referred to as type locality for many of them. Until today, with more than 750 mineralized rare-element granitic pegmatites, the BPP remains a main source of Ta in Brazil, the second most important tantalum-producing country in the world (Magyar 2007). It is also an important resource of raw materials for the Brazilian ceramics industry and of gemstones, including aquamarine, morganite and the highquality turquoise-blue 'Paraíba Elbaite.'

The estimated historic minimum bulk production is on the order of 3,000 tons of tantalite, 20,000 tons of beryl and 1,000 tons of cassiterite. Today, rare-element mineral concentrates are exploited only sporadically as byproducts of kaolin and feldspar mining and from gem quality tourmaline mining in a few pegmatite bodies.

Mineral chemistry data on $\mathrm{Nb}-\mathrm{Ta}-(\mathrm{Ti}-\mathrm{Sn})$ oxides from the BPP are scarce, as reported by Adusumili (1978, and older references therein). Rare, individual data on exotic mineral species were obtained for mineralogical purposes (Burke et al. 1969, 1970; Ercit et al. 1985, 1986, 1992a, b). So far, no attempts were made to relate the mineralogcial data to the geological framework or to provide a pegmatite type (and subtype) classification.

This paper presents more than 550 new mineral chemistry data obtained on samples that contain columbite, ixiolite, tapiolite wodginite and rutile group minerals from 33 different pegmatites (including data from previous works). The data was used to evaluate the usefulness of $\mathrm{Nb}-\mathrm{Ta}-(\mathrm{Ti}-\mathrm{Sn})$ oxide mineral chemistry in the BPP as tracer for the degree of pegmatite fractionation, classification and, mainly, as a tool for a distinction between barren and fertile pegmatites.

\section{Geology}

The BPP, as defined by Scorza (1944), extends over an area of approximately $75 \times 150 \mathrm{~km}$, in the eastern-southeastern part of the Serido foldbelt within the Rio Grande do Norte Tectonic Domain, in the States of Paraíba and Rio Grande do Norte, in northeastern Brazil (Fig. 1). The Seridó foldbelt in this area is made up by the Jucurutú, Equador and Seridó Formations of the Neoproterozoic Seridó Group (Van Schmus et al. 2003). The formation of the mineralized pegmatites is proposed to be related to granites of a late- to post-tectonic phase (Araújo et al. 2001), distinguished as G4 granites, according to the tectonic granite classification by Jardim de Sá et al. (1981) and discussed below in detail.

About $80 \%$ of the mineralized rare-element granitic pegmatites are intruded in garnet-cordierite and/or sillimanite-biotite schists of the uppermost Seridó Formation, about $11 \%$ in the directly underlying quartzites, metarkoses and metaconglomerates of the Equador Formation (Da Silva et al. 1995). The remaining $9 \%$ of the pegmatites are hosted by gneisses and skarns of the Jucurutú Formation, by late G3 and G4 granites (Jardim de Sá et al. 1981), or by gneisses and migmatites of the Paleoproterozoic basement sequence. The regional metamorphism of the Seridó Group reached the low pressure-high temperature Abukuma-type metamorphism of amphibolite grade (Lima 1986). Retrograde metamorphism to the upper greenschist facies is observed and related to the D4 deformation phase.

A regional zoned distribution of the mineralized pegmatites was postulated by Cunha e Silva (1981, 1983), where some small distal fields of rare-earth element-bearing pegmatites are successively followed inwards by a zone dominated by ( $\mathrm{Li}-)$ Sn-bearing pegmatites, an intermediate zone dominated by beryl-bearing pegmatites and an inner, beryl-tantalite-bearing zone with small central areas of pegmatites dominated by tantalite mineralization. This zoning model, however, is not consistent because: (1) in the so-called ( $\mathrm{Li}-) \mathrm{Sn}$ zone, there is a considerable number of pegmatites that are devoid of cassiterite and only mined for tantalite/tapiolite, (2) cassiterite is a common accessory mineral, associated with columbite group minerals in the inner, so called Ta-Be zone (Da Silva et al. 1995), (3) a large central source pluton, as expected, does not exist or is not exposed and (4) the central position in the BPP according to this model is occupied by the most fractionated, Ta-richest pegmatites, whereas less fractionated, Be-rich and rare-earth element-rich pegmatites are found in a more distal position, in disagreement with regional zoning models proposed in the literature elsewhere (e.g. Černý 1989b).

Jardim de Sá et al. (1981) classified the numerous granite types found in the Seridó Belt and the BPP in four main groups, $\mathrm{G} 1$ to $\mathrm{G} 4$, according to their relationship with the four main deformation phases (D1 to D4) in the area. Granites of the G1 group are represented by orthogneisses (mostly augen-gneisses), with their occurrence restricted to the Paleoproterozoic basement of the Caico Group, and are deformed by the first (D1) and all subsequent deformational events. The G2 group granites, including three subgroups, correspond to pre- or early-tectonic orthogneisses intruded in meta-sedimentary rocks of the Seridó Group, intensively deformed by isoclinal folding (thrust-related, 'tangencial', 


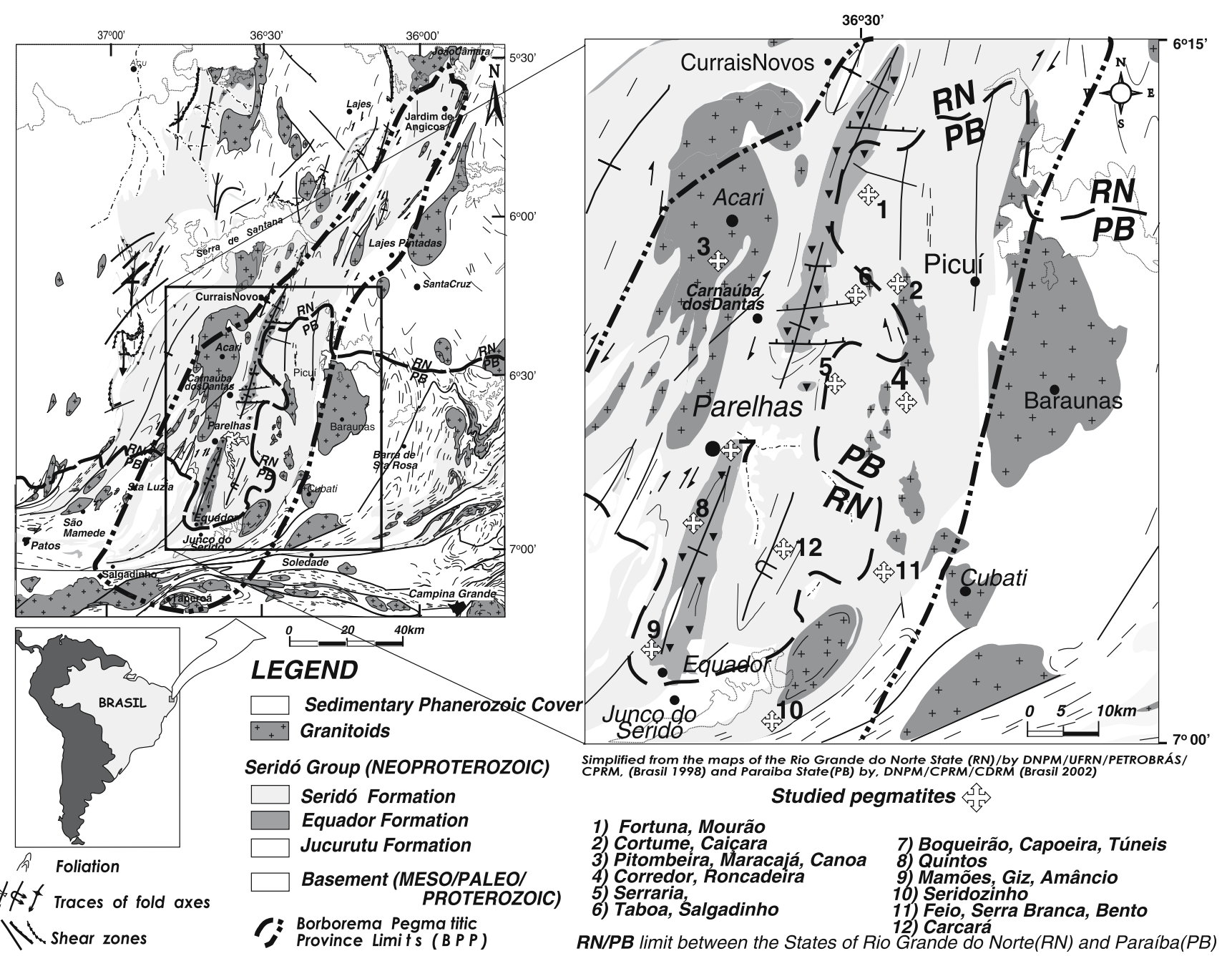

Fig. 1 Simplified geological map of the Borborema Pegmatitic Province with location of the studied pegmatites, adapted from Brasil (1998, 2002)

D2 deformation) and later events. The G3 group granites (including subgroups G3A to G3C) are syn- to late-tectonic with regards to the third deformation event (D3) in the area, characterized by transcurrent shearing and upright, normal folding with vertical to sub-vertical axial planes. The G4 group granites are late to post-tectonic, with respect to the D3 deformation.

The four subgroups of Neoproterozoic ('Brasiliano Cycle')-aged granites relate to the phases G3 and G4 (Jardim de Sá et al. 1981) and occur as several independent intrusions of random distribution. Field relationships do not allow inferring any correlation between the pegmatite mineralization and the intrusion(s). The lack of connection to a central granite intrusion led Ebert (1970) to postulate a palingenetic origin for the mineralized pegmatites in the BPP.

Most authors (Da Silva 1993; Da Silva et al. 1995; Jardim de Sá et al. 1981; Araújo et al. 2001) agree that small stocks and dykes (usually less than $0.3 \mathrm{~km}^{2}$ in area but in a few cases reaching up to $40 \mathrm{~km}^{2}$ ) of leucocratic (barren) pegmatitic granites (apparently related to granites of the G4 phase of Jardim de Sá et al. 1981), and synchronous with the D4 deformation event are the most probable parental granites of the mineralized pegmatites because of their peraluminous character and trace-element geochemistry. No volumetrically larger granite source for these small pegmatitic granite stocks has so far been proposed.

Uranium- $\mathrm{Pb}$ (uraninite) and $\mathrm{Rb}-\mathrm{Sr}$ ages of the pegmatites (Ebert 1969; Almeida et al. 1968) indicate their formation between 450 and $530 \mathrm{Ma}$. The Ar-Ar biotite ages (Araújo et al. 2005) and U-Pb columbite ages (Baumgartner et al. 2006), more recently obtained on pegmatites with low degree of fractionation and weak internal zoning, are 525 and 509-515 Ma, respectively. All these geochronological data of pegmatites are much younger than the 570-Ma (or older) ages, so far obtained for some of the main, larger, G3 and G4 granite intrusions 
(Legrand et al. 1991; Jardim de Sá 1994; Jardim de Sá et al. 1986). The U-Pb monazite ages of $535 \pm 4.1 \mathrm{Ma}$ obtained by Baumgartner et al. (2001) or of $528 \pm 12 \mathrm{Ma}$, according to Baumgartner et al. (2006) for one of these small peraluminous pegmatititic granite stocks, do not support the interpretation of this granite subtype being the source for the pegmatites. The high frequency of small granite bodies in the area allows the interpretation that the BPP is composed of several smaller pegmatite fields, each one with its own separate source and zonal distribution, overlapping each other in many locations. This latter aspect may explain the inefficiency in trying to establish a unique regional zoning model. The geochronological data of pegmatites and related granites in the BPP are quite similar to those summarized by Morteani et al. (2000) for the 'Eastern Brazilian Pegmatite Province' in the State of Minas Gerais, southeastern Brazil.

The pegmatites of the BPP were first classified, based on field observations, as homogeneous (usually barren, frequently concordant, without internal structure) or heterogeneous, often mineralized pegmatites (Johnston 1945). Later, the term 'intermediate' (Rolff 1946) or 'mixed' (Roy et al. 1964) pegmatites was introduced for those mineralized pegmatites that showed an incomplete or unclear internal zoning pattern. This classification is problematic because the designation as homogeneous is locally used for both poorly fractionated pegmatites with incomplete zoning and highly fractionated mineralized pegmatites where the original zoned structure is partially or completely erased by late replacement pockets. Another problem with the classification of the pegmatites according to internal structure is that the zoning pattern clearly changes along the vertical or horizontal extent of individual pegmatite bodies, as shown in Fig. 2. In the Boqueirão pegmatite, the complete sequence of four zones of the model by Johnston (1945) is only observed in the median part of the pegmatite, whereas the western part (likely representing the root of the pegmatite) is poorly zoned or unzoned, like the homogeneous, barren pegmatites. The eastern (apical?) part of the pegmatite becomes gradually homogeneous by increasing abundance of albite- and tourmaline-rich 'replacement pockets.' This change in the zoning pattern parallel to the

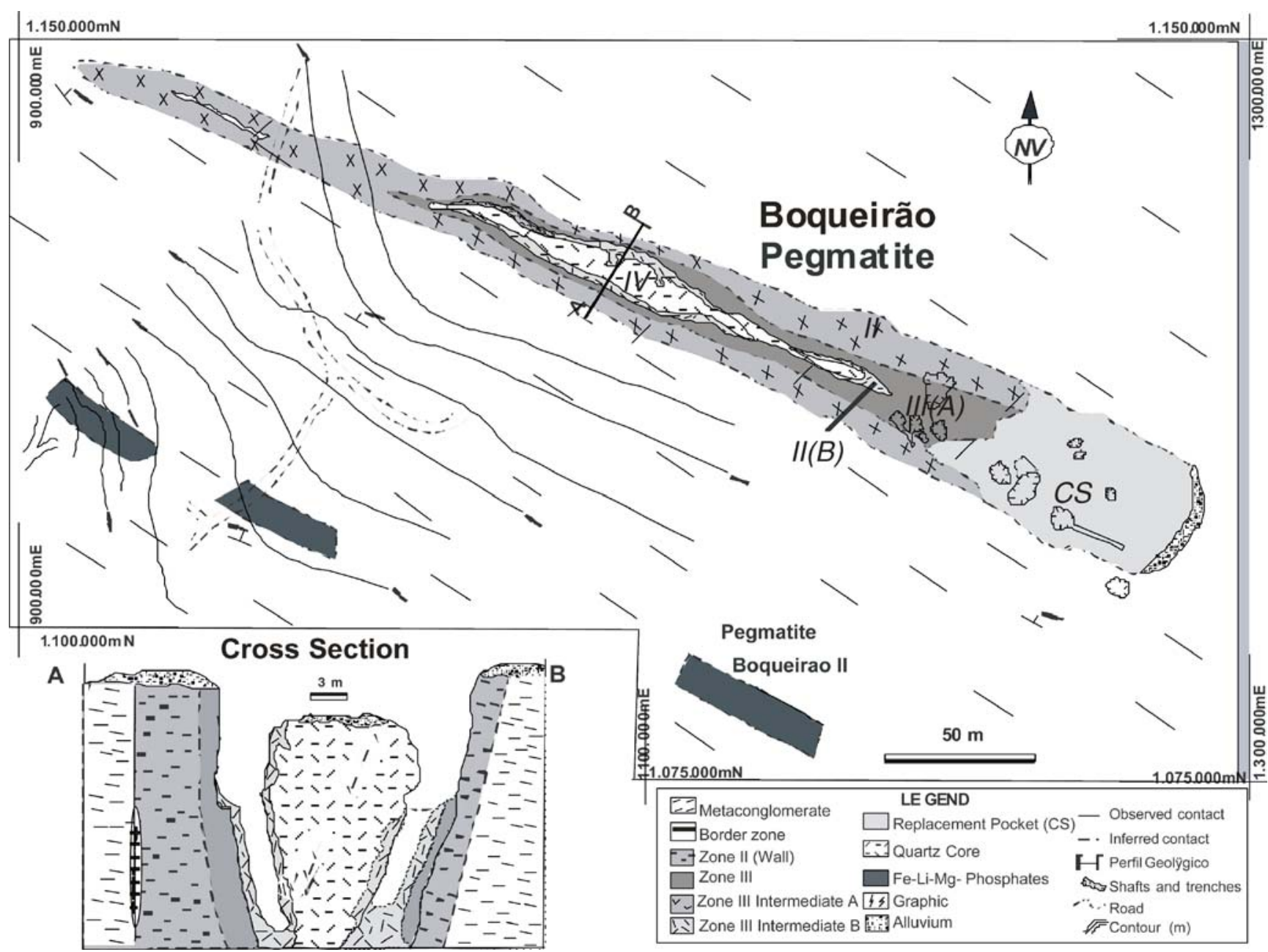

Fig. 2 Geologic map and schematic section of the Boqueirão pegmatite as an example of a typical heterogeneous, mineralized rare-element granitic pegmatite of the Borborema Pegmatitic Province, adapted from Soares (2004) and Tavares (2001) 
Table 1 Description of the main characteristics of the studied pegmatites

\begin{tabular}{|c|c|c|c|c|c|c|c|}
\hline Pegmatite/sample & Type & $\begin{array}{l}\text { Dip/Dip } \\
\text { direction }\end{array}$ & $\begin{array}{l}\text { Formation, } \\
\text { host }\end{array}$ & $\begin{array}{l}\text { Type } \\
\text { minerals }\end{array}$ & $\begin{array}{l}\text { Sample type/ } \\
\text { zone }\end{array}$ & $\begin{array}{l}\text { Special } \\
\text { intergrowths }\end{array}$ & Ore mineral association \\
\hline Fortuna/A8 & & $85^{\circ} / 0^{\circ}$ & Seridó, schists & $\mathrm{Brl}$, & Crystal/dump & & Tap, Wdg \\
\hline Bento/A25 & $\mathrm{Be}$ & $90^{\circ} / 80^{\circ}$ & Seridó, schists & $\mathrm{Brl}$ & Concentrate & Exsol Wdg in Cst & Tap, Wdg, Cst \\
\hline Serraria/A27, A31 & $\mathrm{Be}$ & $50^{\circ} / \mathrm{SW}$ & Seridó, schists & $\mathrm{Brl}$ & Concentrate & $\begin{array}{l}\text { Mcl crystals, Rt } \\
(\mathrm{Nb})+\text { Mic alt }\end{array}$ & Mcl, Tap \\
\hline Soares/A-29 & $\mathrm{Be}$ & $90^{\circ} / 150^{\circ}$ & Seridó, schists & Brl, Tpl & Concentrate & & Tap \\
\hline $\begin{array}{l}\text { Seridozinho/ } \\
\text { DRX-01 }\end{array}$ & CplxSpod & $65^{\circ} / 315^{\circ}$ & Seridó, schists & $\begin{array}{l}\text { Brl,Spd, } \\
\text { Mtn }\end{array}$ & Crystal/dump & Wdg exsol in Cst & $\begin{array}{l}\text { Tap, Cst, Rt(Ta), Wdg, } \\
\text { Mcl, }\end{array}$ \\
\hline $\begin{array}{l}\text { Quintos/QB-08, } \\
07,15\end{array}$ & CplxSpod & $60^{\circ} / \mathrm{ENE}$ & $\begin{array}{l}\text { Equador } \\
\text { quartzite }\end{array}$ & $\mathrm{Brl}, \mathrm{Spd}$ & Crystal/wall & $\begin{array}{l}\text { Ixl cryst } \mathrm{Rt}(\mathrm{Nb}) \\
\text { rim, }\end{array}$ & $\begin{array}{l}\text { Mgt, Ilm, Mic, Ixl, Mic } \\
\text { (Bi) } \operatorname{Mict}(U), \text { Gah, Brn }\end{array}$ \\
\hline Caiçara/HB-02 & CplxSpod & & Seridó, schists & $\begin{array}{l}\text { Brl, } \\
\text { Mtn, } \\
\text { Mic }\end{array}$ & Concentrate & $\begin{array}{l}\text { Exsol Btn in Mic } \\
\text { (Bi), Tap exsol in } \\
\text { Cst }\end{array}$ & $\begin{array}{l}\text { Tap, Mic(Bi), Btn, Mtn, } \\
\text { Mcl, Gah, Cst }\end{array}$ \\
\hline $\begin{array}{l}\text { Cortume/HB03, } \\
28\end{array}$ & CplxSpod & $80^{\circ} / 10^{\circ}$ & Seridó, schists & $\mathrm{Brl}$ & Concentrate & & $\mathrm{Fcl}, \mathrm{Mcl}$ \\
\hline Feio/HB04 & $\mathrm{Be}$ & $70^{\circ} / 310^{\circ}$ & Seridó schists & $\mathrm{Brl}, \mathrm{Ap}$ & Concentrate & $\begin{array}{l}\mathrm{Rt}(\mathrm{Nb}) \text { cryst Ixl, } \mathrm{Fcl} \\
\text { alt to Frs }\end{array}$ & Fcl, Frs, Rt(Nb), Cst, \\
\hline Branco/HB05 & CplxSpod & $70^{\circ} / 140^{\circ}$ & Seridó schists, & $\begin{array}{l}\text { Brl, } \\
\text { Mtn, } \\
\text { Mic }\end{array}$ & Concentrate, & Reverse zoning Mtn & Mtn, \\
\hline $\begin{array}{l}\text { Pitombeira/HB- } \\
\text { 06, Mourão/ } \\
\text { HB07 }\end{array}$ & $\mathrm{Be}$ & $35^{\circ} / \mathrm{NE}$ & $\begin{array}{l}\text { Acarí Granite, } \\
\text { Seridó schists }\end{array}$ & $\mathrm{Brl}$ & $\begin{array}{l}\text { Crystal/wall+ } \\
\text { Concentrate }\end{array}$ & $\begin{array}{l}\text { Ixl exsol in Rt(Ta) } \\
\text { criystals }\end{array}$ & Mgt, Ilm, Fcl, Tap \\
\hline Taboa/HB09 & $\mathrm{Be}$ & $75^{\circ} / 90^{\circ}$ & Seridó schists & $\mathrm{Brl}$ & Concentrate & $\begin{array}{l}\text { Ixl+Cst exsol in } \\
\mathrm{Ilm}\end{array}$ & Ilm, Fcl, Mcl ,Tap \\
\hline Salgadinho/HB11 & CplxSpod & $80^{\circ} / 0^{\circ}$ & Seridó schists & $\begin{array}{l}\text { Brl,Spd, } \\
\text { Amb }\end{array}$ & Crystal/dump & Patchy zonation & Tap \\
\hline $\begin{array}{l}\text { Boqueirão } 1 \text { and } \\
\text { 2/HB12, } 01\end{array}$ & CplxSpod & $75^{\circ} / 0^{\circ}$ & $\begin{array}{l}\text { Equador } \\
\text { conglo- } \\
\text { merate }\end{array}$ & $\begin{array}{l}\text { Brl,Spd, } \\
\text { Tpl }\end{array}$ & $\begin{array}{l}\text { Crystal/ } \\
\text { intermediate }\end{array}$ & $\begin{array}{l}\text { Mcl, alteration to Rt } \\
(\mathrm{Nb})+\mathrm{Mic}\end{array}$ & Mcl, Mtn \\
\hline Giz/HB14, A40 & CplxSpod & $35^{\circ} / 290^{\circ}$ & $\begin{array}{l}\text { Equador } \\
\text { quartzite }\end{array}$ & $\begin{array}{l}\text { Brl,Spd, } \\
\text { Mtn }\end{array}$ & Crystal/dump & Reverse zoning & $\begin{array}{l}\text { Mtn, Smp, Mrl, Mic } \\
\text { (Ba) }\end{array}$ \\
\hline Amâncio/HB17 & CplxSpod & $90^{\circ} / 310^{\circ}$ & $\begin{array}{l}\text { Equador } \\
\text { quartzite }\end{array}$ & Brl,Mtn & Crystal/dump & Reverse zoning & Mtn, Mcl \\
\hline Mamões/HB18 & CplxSpod & $85^{\circ} / 305^{\circ}$ & $\begin{array}{l}\text { Equador } \\
\text { quartzite }\end{array}$ & $\begin{array}{l}\text { Brl, } \\
\text { Mtn, } \\
\text { Mic }\end{array}$ & Crystal/dump & Reverse zoning & Mtn \\
\hline Canoa/HB19, 32 & $\mathrm{Be}$ & $45^{\circ} / \mathrm{NE}$ & Acari Granite & $\mathrm{Brl}$ & Crystal/wall & $\begin{array}{l}\text { Ixl exsol in } \mathrm{Rt}(\mathrm{Ta}) \\
\text { crystals }\end{array}$ & Mgt, Ilm, Rt(Ta),.Ixl \\
\hline Carcará/HB20, 07 & & $80^{\circ} / 20^{\circ}$ & & & Crystal/dump & $\begin{array}{l}\text { Tap crystal, Mic }+ \\
\text { Ftn alt }\end{array}$ & Tap, Mlt \\
\hline $\begin{array}{l}\text { Capoeiras } 1,2 \\
\text { and } 3 / \mathrm{HB} 21 \text {, } \\
\text { CA-03 }\end{array}$ & CplxSpod & $50^{\circ} / 0^{\circ}$ & $\begin{array}{l}\text { Equador } \\
\text { conglo- } \\
\text { merate }\end{array}$ & $\mathrm{Brl}, \mathrm{Spd}$ & $\begin{array}{l}\text { Crystal/ } \\
\text { intermediate+ } \\
\text { elluvium }\end{array}$ & Ixl exsol in $\mathrm{Rt}(\mathrm{Nb})$. & $\begin{array}{l}\text { Mt, Ilm, Mic,Gah, Mcl, } \\
\text { Ixl }\end{array}$ \\
\hline Túneis/HB22 & CplxSpod & $80^{\circ} / 70^{\circ}$ & $\begin{array}{l}\text { Equador } \\
\text { quartzite }\end{array}$ & $\begin{array}{l}\text { Mtn, } \\
\text { Mic }\end{array}$ & $\begin{array}{l}\text { Crystal/core }+ \\
\text { concentrate }\end{array}$ & $\begin{array}{l}\text { Reverse zoning } \\
\text { Mtn, patchy }\end{array}$ & Mtn, Mic(U). \\
\hline Corredor/HB-24B & $\mathrm{Be}$ & $70^{\circ} / \mathrm{ESE}$ & Seridó schists & $\begin{array}{l}\mathrm{Brl}, \\
\mathrm{Cbl},\end{array}$ & Crystal/border & $\begin{array}{l}\text { Rt(Ta), Wdg exsol. } \\
\text { in Cst }\end{array}$ & $\begin{array}{l}\text { Fcl, Tap, Wdg, Cst, Rt } \\
\text { (Ta). }\end{array}$ \\
\hline $\begin{array}{l}\text { Roncadeira/HB- } \\
\text { 24A, A-28 }\end{array}$ & $\mathrm{Be}$ & $70^{\circ} / \mathrm{ESE}$ & Seridó schists & $\mathrm{Cbl}$ & $\begin{array}{c}\text { Crystal/wall+ } \\
\text { concentrate }\end{array}$ & $\begin{array}{l}\mathrm{Ixl}+\mathrm{Rt}(\mathrm{Nb}) \text { zoned } \\
\text { crystals }\end{array}$ & $\begin{array}{l}\text { Fcl, Tap, Cast, Wdg, } \\
\text { Ftn, }\end{array}$ \\
\hline
\end{tabular}

Classification based mainly on mineral chemistry, including $\mathrm{Nb}-\mathrm{Ta}$ oxide information provided in this paper.

Pegmatite types: Be Beryl type, beryl-columbite phosphate subtype; CplxSpod complex spodumene or lepidolite subtype. Mineral abbreviations, according to Kretz (1983) when possible: Tap ferrotapiolite, Wdg wodginite, Cst cassiterite, $M c l$ manganocolumbite, $R t(T a)$ strüverite, $M i c$ microlite, Mgt magnetite, Ilm ilmenite, Gah gahnite, $\mathrm{Fcl}$ ferrocolumbite, Frs fersmite, Brn brannerite, Ixl titanian ixiolite, Mtn manganotantalite, Smp simpsonite, Rt(Nb) Niobian rutile, Btn Bismutotantalite, Amb amblygonite, montebrasite, Ap apatite, Brl beryl, Cbl Chrysoberyl, Spd spodumene, $T p l$ triplite, triphylite, litiophylite, exsol exsolution bodies, alt alteration, $O b s$. the column on type minerals includes non-opaque minerals referred to in the literature or observed by the authors 

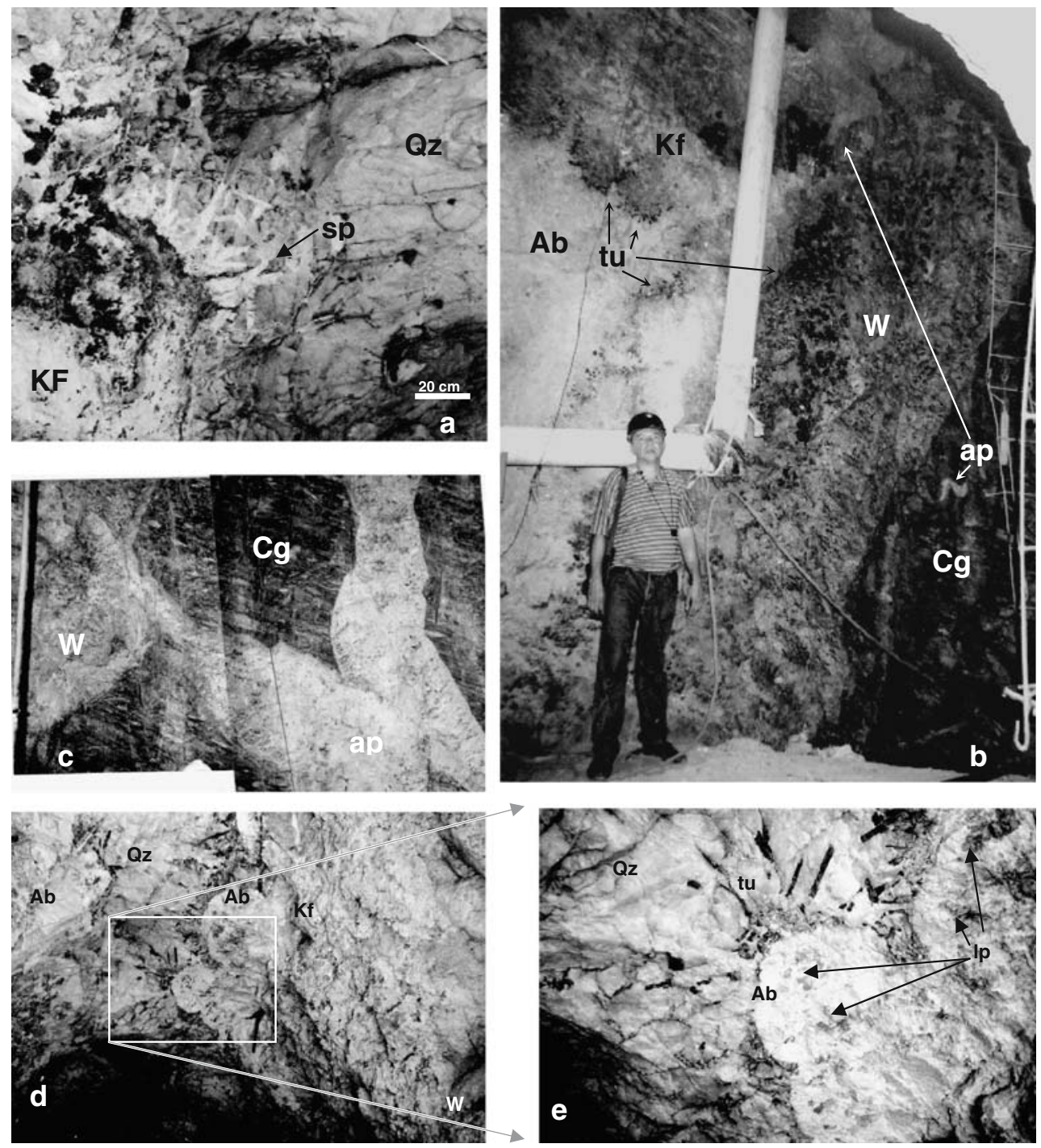

Fig. 3 a Photo of large tabular spodumene ( $s p$ ) crystals (up to $80 \mathrm{~cm}$ long) with radial arrangement, with the roots in the intermediate blocky K-spar zone $(K F)$ and growing into the former open space, which is now filled by the quartz core $(Q z)$, from the Boqueirão pegmatite. b Cross-section of the Capoeira 2 pegmatite. The contact with the metaconglomeratic host rock at the right $(\mathrm{Cg})$ starts with a border zone composed of sacharoidal fine-grained K-feldspar+albite+ quartz \pm garnet \pm black tourmaline (dravite) and culminates with a discontinuous fringe of comb-textured to radially textured dravite, followed by a medium to coarse-grained wall zone $(W)$ composed by $\mathrm{K}$-feldspar $>$ quartz $>$ albite $>$ schorlite-dravite. The wall zone grades inwards to a coarse-grained intermediate zone enriched in blocky $\mathrm{K}$ feldspar $(K f)$, followed by a new fringe of rosette-like textured schorlite-dravite $(t u)$ at the transition to an albite-rich, inner

longitudinal extent of the pegmatite illustrates the need of careful 3D examination of a pegmatite, before classification. Indeed, the geological map of this pegmatite is similar to the model of pegmatite classification proposed by Vlasov (1952), which synthesizes four pegmatite types into one composite body. intermediate zone $(a b)$. At the upper part the albite-rich zone invades the wall zone, cross-cutting the tourmaline fringe. Note also the small $\mathrm{s}$-shaped albite-rich vein in the metaconglomerate, considered to be an apophysis $(a p)$. c Detail of an albite-rich vein cross-cutting the wall and border zones to form large apophyses ( $2 \mathrm{~m}$ high by $1 \mathrm{~m}$ thick) of albitic pegmatite with comb-textured tourmaline forming a border zone. d Partial cross-section of the Carrascão pegmatite, with a wall zone $(W)$ composed by a medium-grained aggregate of K-feldspar+ quartz + muscovite \pm albite \pm garnet, at the left, grading into a poorly developed zone of blocky K-feldspar $(K f)$ followed by a zone of rosette-like aggregates of cleavelandite $(A b)$ and columnar lepidolite $(l p)$, growing inwards into the (former open space) quartz core $(Q z)$ seen in detail in e. e Deatil of quartz core (scale: size of the tourmaline crystals up to $15 \mathrm{~cm}$ )

Another attempt to classify the pegmatites of the BPP based on main ore minerals is implicitly proposed by the regional zoning model (Cunha e Silva 1983), discussed above. Because of the incomplete record of accessory minerals other than beryl, columbite-tantalite and spodumene, observed or documented during the main mining 
periods in the decades 1940 to 1960 , it is almost impossible to try to improve this kind of classification today.

A first attempt to classify the mineralized pegmatites of the BPP based mainly on trace-element geochemistry in feldspars and micas was performed on ten mineralized pegmatites by Da Silva (1993) and Da Silva et al. (1995). Based on geochemical data, these authors assigned the pegmatites of the BPP to the beryl-columbite phosphate subtype of the rare-element pegmatite group as proposed by Černý (1991), regardless of the presence or absence of phosphates. As a consequence, a poor to moderate degree of differentiation was assumed for all pegmatites of the BPP until recently, when mineral chemistry data on tourmalines, garnet and spinel and trace-element geochemistry in micas and feldspar indicated a higher degree of fractionation for the mineralized Quintos and Capoeira 2 pegmatites, which Soares (2004) classified as spodumene or lepidolite subtype, in agreement with their important spodumene and lepidolite mineralization.

According to Johnston (1945), in a typical "heterogeneous" (zoned) and mineralized granitic pegmatite of the BPP, the following zones, from the margins to the center, may be observed: Zone I is composed typically of combtextured muscovite (or tourmaline, and/or laminar ferrocolumbite and/or biotite), intergrown with medium-grained albite-oligoclase and quartz, zone II is defined by a homogeneous, medium-grained K-spar + quartz \pm albite pegmatite with frequent graphic inter-growths of quartz and perthite and inwards increasing grain size, zone III is composed almost exclusively of large perthite crystals (blocky feldspar zone), and zone IV corresponds to a monomineralic nucleus of massive (milky and/or rose) quartz. This schematic model of internal structure is almost identical to the worldwide accepted model by Cameron et al. (1949), i.e. border, wall, intermediate, and core zone. Most of the pegmatites studied in the present paper are classical examples of this zonation (Fig. 2, Table 1). The contact between zones III and IV was recognized as the preferential site of mineralization by Johnston (1945). The frequently mineralized 'replacement bodies' (Cameron et al. 1949) in the BPP also occur preferentially close to this contact (Da Silva et al. 1995). They consist of decimetre- to metre-sized irregular pockets of medium- to fine-grained cleavelandite and/or muscovite and/or lepidolite selvages (recognized as 'MP' units=mica pockets, according to Roy et al. 1964), with some phosphates and disseminated ore minerals. The highest Ta ore concentrations and grades in the BPP occur around this contact, within or unrelated to the replacement pockets. Huge individual crystals of beryl (up to 50 tons), spodumene (several tons), tantalite (up to $1,000 \mathrm{~kg}$ ) or cassiterite (up to $400 \mathrm{~kg}$ ) are also found at this contact (Rolff 1946). Frequently, the roots of the crystals in the transition from zone III to IV (cleavelandite and lepidolite roses, radial tourmaline aggregates and spodumene, beryl, tantalite crystals) start growing in the blocky feldspar zone, whereas the crystal tips grow idiomorphically into the former open space, now filled by the quartz core. These textural relations are in accordance to the interpretation by London (1992) and indicate that these minerals may be primary crystallization products before the formation of the quartz core and do not always belong to a replacement body (Figs. 3a-e, 4a,b) as generally proposed in the BPP for cleavelandite, lepidolite and tourmaline aggregates. A primary origin of some of these albite + mica-

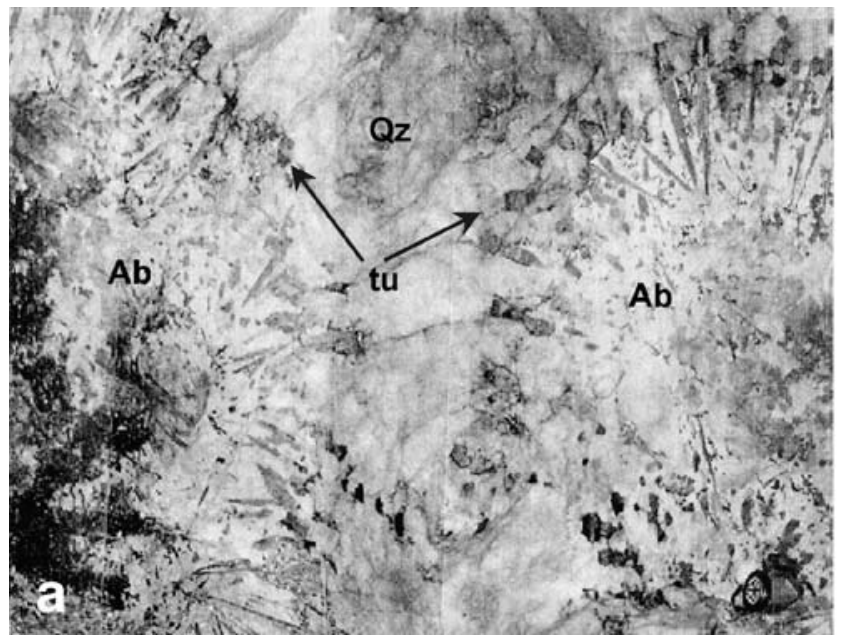

Fig. 4 a Identical textural relations as in Fig. 3 are now observed between cleavelandite $(A b)$, bi-colored elbaite (rose and light blue "Paraíba elbaite", $t u$ ) growing from the inner intermediate zone towards the quartz $(Q z)$ of the core from the Quintos pegmatite (photo from Barreto 2000). Scale: tourmaline crystal $17 \mathrm{~cm}$ long. b Detail of a,

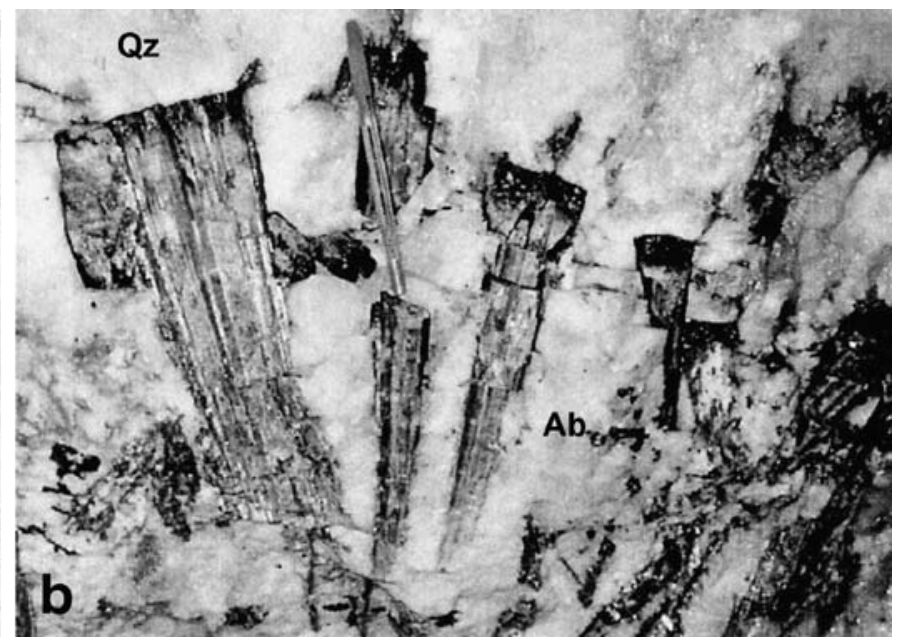

showing the pinacoidal terminations of the zoned tourmaline crystals idiomorphic against quartz and tabular albite at the transition to the quartz core and the imbricate inter-growth with albite and quartz at the roots of the crystals, in the inner intermediate zone 


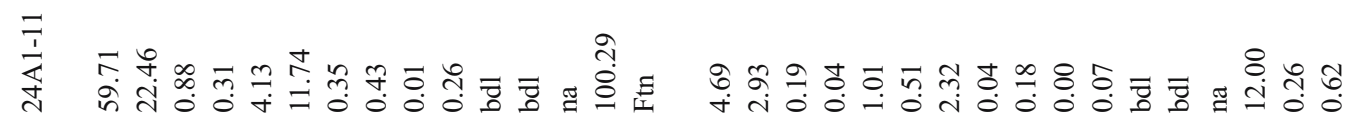

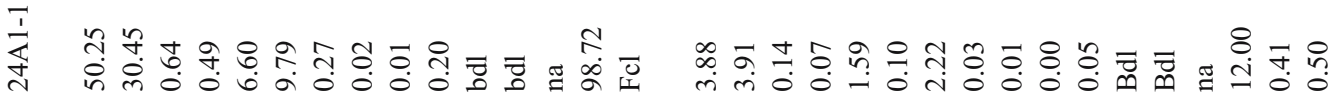

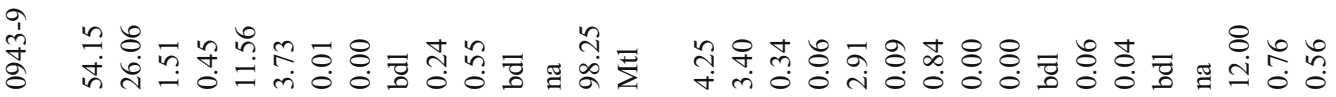

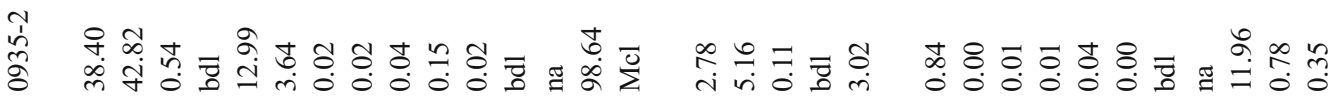

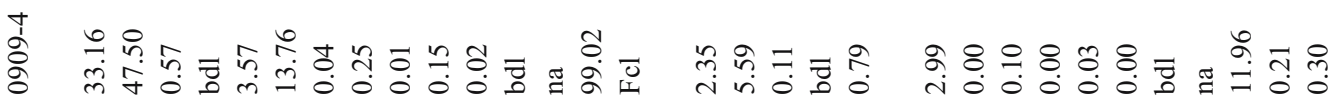

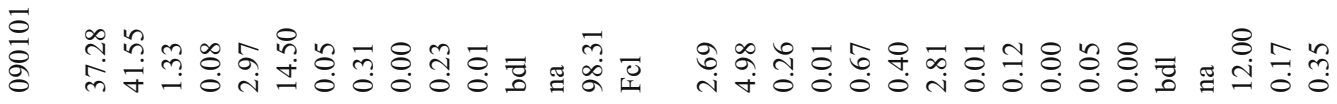

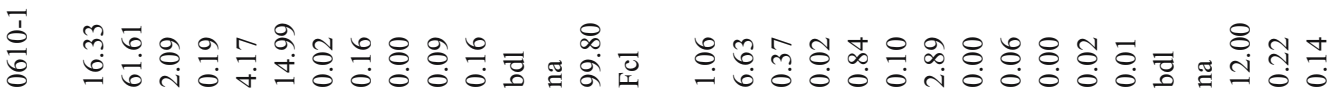

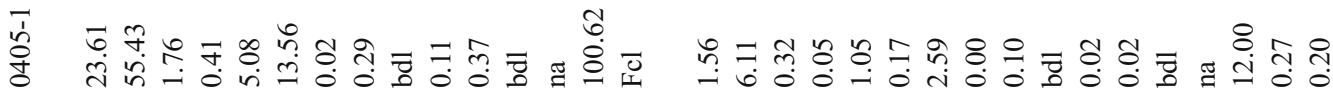

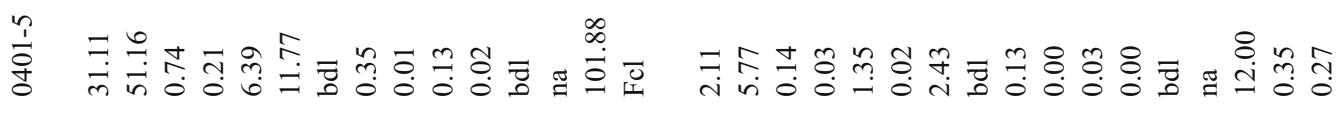

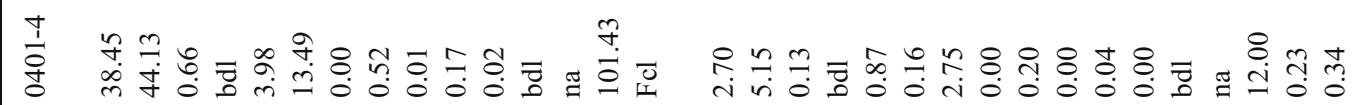
象 जिएव.<smiles>[CH][CH]</smiles> 


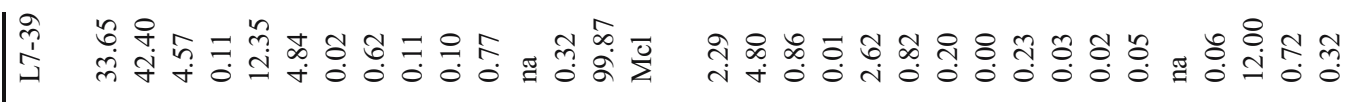

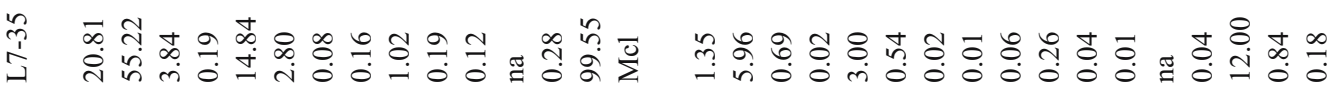

荀

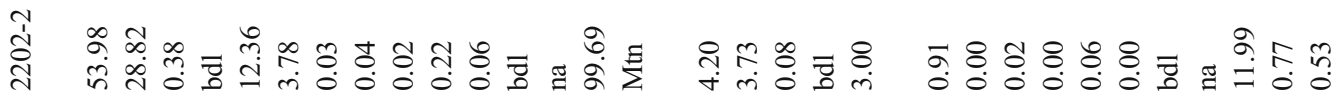

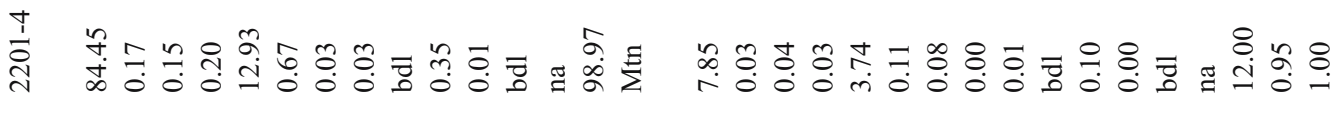

先

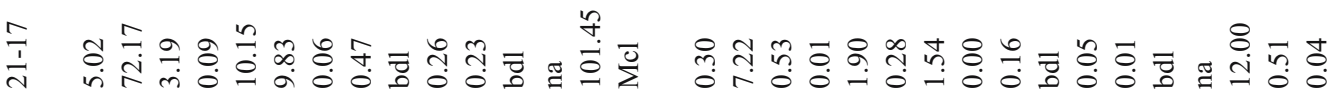

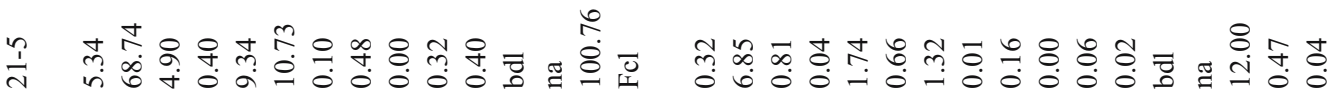

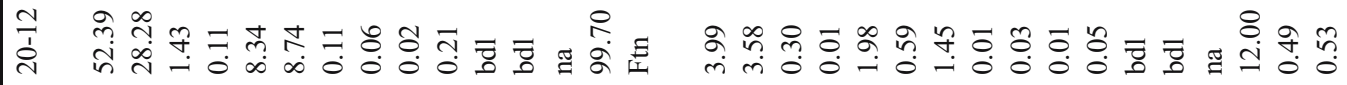

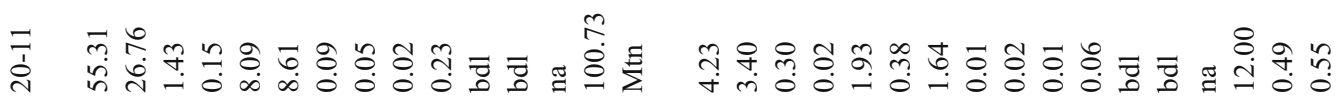

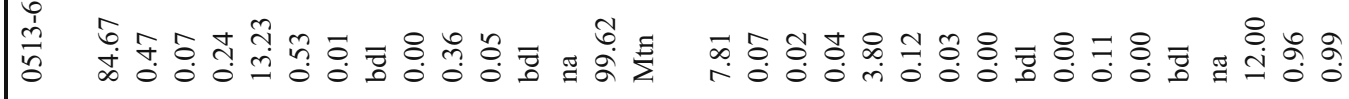

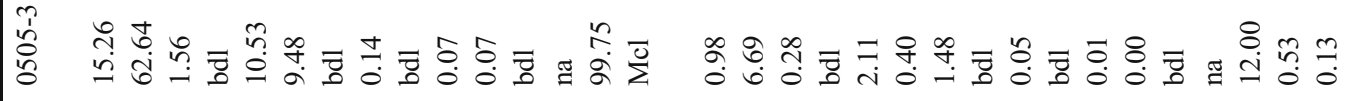

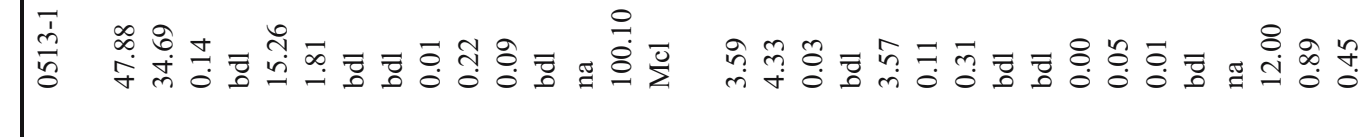

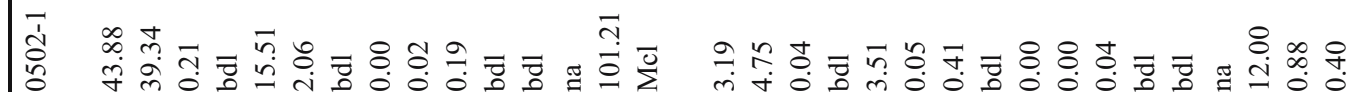


Table 3 Selected representative EMPA data of Nb-Ta-(Ti-Sn) oxides from the BPP (continued)

\begin{tabular}{|c|c|c|c|c|c|c|c|c|c|c|}
\hline \multirow{3}{*}{$\begin{array}{l} \\
\text { Sample } \\
\text { Weight percent }\end{array}$} & \multicolumn{10}{|c|}{ Anomalous (reverse)-zoned crystals } \\
\hline & $0923-6$ & $0923-7$ & $0508-1$ & $0508-4$ & L7-1 & L7-25 & L7-32 & L7-47 & 24B4-8 & 24B4-6 \\
\hline & & & & & & & & & & \\
\hline $\mathrm{Ta}_{2} \mathrm{O}_{5}$ & 26.09 & 40.56 & 45.27 & 85.08 & 11.08 & 19.43 & 35.11 & 43.06 & 44.34 & 55.62 \\
\hline $\mathrm{Nb}_{2} \mathrm{O}_{5}$ & 55.23 & 40.58 & 37.58 & 0.72 & 34.25 & 30.46 & 25.33 & 16.53 & 12.36 & 28.29 \\
\hline $\mathrm{TiO}_{2}$ & 0.43 & 0.70 & 0.17 & 0.17 & 32.05 & 27.74 & 15.83 & 20.10 & 22.72 & 0.55 \\
\hline $\mathrm{ZrO}_{2}$ & bdl & 0.04 & bdl & 0.19 & 0.20 & 0.25 & 0.46 & 0.55 & 0.08 & 0.02 \\
\hline $\mathrm{MnO}$ & 4.32 & 3.48 & 15.27 & 13.19 & 0.48 & 0.53 & 1.43 & 1.82 & 0.06 & 3.54 \\
\hline $\mathrm{FeO}$ & 13.80 & 13.22 & 1.81 & 0.51 & 20.06 & 19.86 & 19.59 & 16.68 & 14.46 & 12.19 \\
\hline $\mathrm{SnO}_{2}$ & 0.02 & 0.04 & bdl & 0.02 & 0.39 & 0.46 & 0.12 & 0.10 & 4.68 & 0.11 \\
\hline $\mathrm{MgO}$ & 0.21 & 0.25 & 0.01 & 0.01 & 0.12 & 0.17 & 0.36 & 0.39 & 0.03 & 0.62 \\
\hline $\mathrm{CaO}$ & bdl & 0.01 & 0.02 & 0.03 & 0.01 & 0.01 & 0.00 & bdl & bdl & 0.01 \\
\hline $\mathrm{Sc}_{2} \mathrm{O}_{3}$ & 0.10 & 0.18 & 0.19 & 0.34 & 0.12 & 0.13 & 0.06 & 0.09 & 0.19 & 0.26 \\
\hline $\mathrm{UO}_{2}$ & 0.03 & 0.07 & bdl & bdl & 0.19 & 0.24 & 0.40 & 0.43 & bdl & 0.03 \\
\hline $\mathrm{Y}_{2} \mathrm{O}_{3}$ & bdl & bdl & bdl & bdl & bdl & bdl & bdl & bdl & bdl & bdl \\
\hline$\sum$ others & na & na & na & na & 0.30 & 0.27 & 0.46 & 0.59 & na & na \\
\hline Total & 100.23 & 99.12 & 100.33 & 100.25 & 99.26 & 99.55 & 99.14 & 100.33 & 98.91 & 101.23 \\
\hline Mineral & $\mathrm{Fcl}$ & $\mathrm{Fcl}$ & $\mathrm{Mcl}$ & Mtn & $\mathrm{Rt}(\mathrm{Nb})$ & $\mathrm{Rt}(\mathrm{Nb})$ & $\operatorname{Ixl}(+\mathrm{Nb})$ & $\operatorname{Ixl}(+\mathrm{Ta})$ & Ixl(Ti) & Ftn \\
\hline APFU & rim & $\leftarrow$ core & rim & $\leftarrow$ core & rim & $\leftarrow$ outer & core & $\leftarrow$ core & rim & $\leftarrow$ core \\
\hline $\mathrm{Ta}$ & 1.76 & 2.95 & 3.35 & 7.79 & 0.60 & 1.09 & 2.21 & 2.73 & 2.95 & 4.25 \\
\hline $\mathrm{Nb}$ & 6.18 & 4.90 & 4.62 & 0.11 & 3.06 & 2.85 & 2.65 & 1.74 & 1.37 & 3.59 \\
\hline $\mathrm{Ti}$ & 0.08 & 0.15 & 0.04 & 0.04 & 4.77 & 4.32 & 2.75 & 3.53 & 4.19 & 0.12 \\
\hline $\mathrm{Zr}$ & bdl & 0.00 & bdl & 0.03 & 0.02 & 0.03 & 0.05 & 0.06 & 0.01 & 0.00 \\
\hline $\mathrm{Mn}$ & 0.93 & 0.81 & 3.52 & 3.76 & 0.08 & 0.09 & 0.28 & 0.36 & 0.01 & 0.84 \\
\hline $\mathrm{Fe}^{3+}$ & & 0.11 & & 0.04 & 3.29 & 3.29 & 3.66 & 3.19 & 1.69 & 0.16 \\
\hline $\mathrm{Fe}^{2+}$ & 2.94 & 2.93 & 0.41 & 0.11 & 0.03 & 0.14 & 0.13 & 0.07 & 1.27 & 2.71 \\
\hline $\mathrm{Sn}$ & 0.00 & 0.00 & bdl & 0.00 & 0.03 & 0.04 & 0.01 & 0.01 & 0.46 & 0.01 \\
\hline $\mathrm{Mg}$ & 0.08 & 0.10 & 0.00 & 0.01 & 0.04 & 0.05 & 0.12 & 0.13 & 0.01 & 0.26 \\
\hline $\mathrm{Ca}$ & bdl & 0.00 & 0.00 & 0.01 & 0.00 & 0.00 & 0.00 & bdl & bdl & 0.00 \\
\hline $\mathrm{Sc}$ & 0.02 & 0.04 & 0.05 & 0.10 & 0.02 & 0.02 & 0.01 & 0.02 & 0.04 & 0.06 \\
\hline $\mathrm{U}$ & 0.00 & 0.00 & bdl & bdl & 0.01 & 0.01 & 0.02 & 0.02 & bdl & 0.00 \\
\hline $\mathrm{Y}$ & bdl & bdl & bdl & bdl & bdl & bdl & bdl & bdl & bdl & bdl \\
\hline$\sum$ others & na & na & na & na & 0.06 & 0.06 & 0.10 & 0.13 & na & na \\
\hline Total & 12.00 & 12.00 & 11.99 & 12.00 & 12.00 & 12.00 & 12.00 & 12.00 & 12.00 & 12.00 \\
\hline $\mathrm{Mn} /(\mathrm{Fe}+\mathrm{Mn})$ & 0.24 & 0.21 & 0.90 & 0.96 & 0.02 & 0.03 & 0.07 & 0.10 & 0.00 & 0.23 \\
\hline $\mathrm{Ta} /(\mathrm{Ta}+\mathrm{Nb})$ & 0.22 & 0.38 & 0.42 & 0.99 & 0.16 & 0.28 & 0.45 & 0.61 & 0.68 & 0.54 \\
\hline
\end{tabular}

rich aggregates is also in agreement with the interpretation of experimental results on pegmatitic or aplogranitic magmas (London 1992, 1996, 2005). Examples of beryl and tourmaline mineralization at the gradational contact between zones II and III and of spodumene and/or cassiterite in zones I and II are less common.

\section{Sampling and analytical methods}

We collected in situ samples of $\mathrm{Nb}-\mathrm{Ta}-(\mathrm{Ti}-\mathrm{Sn})$ oxides of the Boqueirão (bodies 1 and 2), Quintos, Corredor, Pitombeiras (body 1), Canoa, Túneis and Capoeiras (bodies 2 and 3) pegmatites. In these cases, the exact location and paragenetic position of the minerals in the structure of the host pegmatites are known. Samples of the Mamões, Amâncio, Brennand, Cortume, Roncadeira, Fortuna, Giz, Mourão, Feio, Serraria (1 and 2), Serra Branca and Capoeira 1 pegmatites were either collected from dumps or obtained directly from miners and garimpeiros (precious stone seekers) at the entrance of the 'mine' excavations. In the first six pegmatites of this group, the position of the sample within the structure (and paragenetic position) of these pegmatites can be induced because the oxides are part of a larger sample with typical pegmatite minerals and/or textures. In the case of samples from other pegmatites referred to in Table 1, the location was provided by garimpeiros and mineral dealers.

In a first step, polished sections of crystals and heavy mineral concentrates (embedded in acrylic resin) were 
Table 3 (continued)

\begin{tabular}{|c|c|c|c|c|c|c|c|c|c|c|c|c|c|}
\hline \multicolumn{6}{|c|}{ Normal-zoned Ixiolite exsolutions } & \multicolumn{8}{|c|}{ Phases with special compositions } \\
\hline $0408-1$ & $0408-4$ & $21-1$ & $21-3$ & $19-60$ & $19-50$ & $24 \mathrm{~A} 1-7$ & $24 \mathrm{~A} 1-18$ & $0615-9$ & 0907-1 & A40L1-7 & A4012 10 & A40L2-6 & $20-05$ \\
\hline 68.07 & 56.11 & 6.31 & 6.07 & 27.88 & 30.92 & 53.47 & 59.77 & 39.63 & 10.72 & 61.27 & 63.83 & 45.19 & 77.65 \\
\hline 5.71 & 4.93 & 30.06 & 43.74 & 13.18 & 41.84 & 17.38 & 16.11 & 34.23 & 61.20 & 10.90 & 9.83 & 7.06 & 6.07 \\
\hline 10.59 & 23.09 & 47.16 & 26.82 & 43.28 & 6.64 & 1.47 & 1.19 & 6.05 & 6.09 & 1.22 & 0.56 & 28.99 & 1.29 \\
\hline 0.26 & 0.25 & bdl & 0.36 & 0.06 & 0.72 & 0.10 & 0.89 & 0.55 & 0.55 & 0.68 & 0.27 & 0.17 & 0.06 \\
\hline 0.20 & 0.10 & 0.10 & 0.79 & 0.03 & 7.16 & 0.97 & 2.22 & 7.75 & 9.03 & 2.28 & 5.19 & 0.06 & 1.02 \\
\hline 12.96 & 11.14 & 15.18 & 20.52 & 12.72 & 8.64 & 22.03 & 16.04 & 6.75 & 6.49 & 12.57 & 8.83 & 12.30 & 13.72 \\
\hline 2.79 & 4.47 & 0.32 & 0.39 & 1.35 & 1.05 & 2.67 & 2.04 & 1.73 & 0.20 & 11.55 & 11.25 & 6.27 & 0.07 \\
\hline 0.04 & 0.02 & 0.02 & 0.16 & bdl & 0.09 & 0.09 & 0.29 & 0.11 & 0.09 & 0.34 & 0.14 & 0.04 & 0.01 \\
\hline bdl & bdl & 0.01 & 0.01 & bdl & 0.06 & bdl & bdl & 0.02 & 0.00 & bdl & bdl & bdl & 0.02 \\
\hline 0.29 & 0.23 & 0.06 & 0.14 & 0.39 & 3.17 & 0.22 & 0.25 & 2.73 & 4.62 & 0.11 & 0.09 & 0.11 & 0.32 \\
\hline bdl & bdl & 0.03 & 0.13 & 0.02 & bdl & bdl & bdl & bdl & bdl & bdl & bdl & bdl & 0.01 \\
\hline bdl & bdl & 0.01 & 0.02 & bdl & 0.04 & bdl & bdl & bdl & bdl & na & na & na & bdl \\
\hline na & na & na & na & 0.15 & 0.66 & na & na & na & na & 0.34 & 0.23 & 0.24 & na \\
\hline 100.91 & 100.34 & 99.25 & 99.14 & 99.07 & 100.98 & 98.38 & 98.80 & 99.53 & 99.00 & 101.25 & 100.21 & 100.43 & 100.2 \\
\hline $\begin{array}{l}\text { Wdg(Ti) } \\
\text { rim }\end{array}$ & $\begin{array}{l}\mathrm{Rt}(\mathrm{Ta}) \\
\leftarrow \text { core }\end{array}$ & $\begin{array}{l}\mathrm{Rt}(\mathrm{Nb}) \\
\text { host }\end{array}$ & $\begin{array}{l}\text { Ixl } \\
\text { exsol. }\end{array}$ & $\begin{array}{l}\mathrm{Rt}(\mathrm{Ta}) \\
\text { host }\end{array}$ & $\begin{array}{l}\text { Ixl(Ti) } \\
\text { exsol. }\end{array}$ & Ixl?Fe? & Ixl?(Fe) & Ixl ?(Sc) & $\operatorname{Ixl}(\mathrm{Sc})$ & $\begin{array}{l}\text { Wdg } \\
\text { exsol. }\end{array}$ & $\begin{array}{l}\text { Wdg } \\
\text { exsol. }\end{array}$ & $\operatorname{Rt}(\mathrm{Ta})$ & Tap \\
\hline 5.34 & 3.95 & 0.32 & 0.33 & 1.57 & 2.03 & 3.95 & 4.69 & 2.78 & 0.66 & 4.92 & 5.34 & 2.92 & 6.75 \\
\hline 0.74 & 0.58 & 2.56 & 3.91 & 1.24 & 4.58 & 2.13 & 2.10 & 3.99 & 6.29 & 1.45 & 1.37 & 0.76 & 0.88 \\
\hline 2.30 & 4.49 & 6.67 & 3.99 & 6.76 & 1.21 & 0.30 & 0.26 & 1.17 & 1.04 & 0.27 & 0.13 & 5.18 & 0.31 \\
\hline 0.04 & 0.03 & bdl & 0.04 & 0.01 & 0.08 & 0.01 & 0.13 & 0.07 & 0.06 & 0.10 & 0.04 & 0.02 & 0.01 \\
\hline 0.05 & 0.02 & 0.02 & 0.14 & 0.01 & 1.47 & 0.22 & 0.54 & 1.69 & 1.74 & 0.57 & 1.35 & 0.01 & 0.28 \\
\hline 0.37 & 0.41 & 1.95 & 3.15 & 1.74 & 0.70 & 4.49 & 2.34 & 0.23 & & 1.33 & 0.72 & 1.30 & 0.37 \\
\hline 2.75 & 2.00 & 0.44 & 0.34 & 0.47 & 1.05 & 0.51 & 1.52 & 1.22 & 1.23 & 1.77 & 1.55 & 1.15 & 3.30 \\
\hline 0.32 & 0.46 & 0.02 & 0.03 & 0.11 & 0.10 & 0.29 & 0.23 & 0.18 & 0.02 & 1.36 & 1.38 & 0.59 & 0.01 \\
\hline 0.02 & 0.01 & 0.00 & 0.05 & bdl & 0.03 & 0.03 & 0.12 & 0.04 & 0.03 & 0.15 & 0.06 & 0.01 & 0.00 \\
\hline bdl & bdl & 0.00 & 0.00 & bdl & 0.02 & bdl & bdl & 0.01 & 0.00 & bdl & bdl & bdl & 0.01 \\
\hline 0.07 & 0.05 & 0.01 & 0.03 & 0.07 & 0.67 & 0.05 & 0.06 & 0.61 & 0.91 & 0.03 & 0.03 & 0.02 & 0.09 \\
\hline bdl & bdl & 0.00 & 0.01 & 0.00 & bdl & bdl & bdl & bdl & bdl & bdl & bdl & 0.00 & 0.00 \\
\hline bdl & bdl & 0.00 & 0.00 & bdl & 0.01 & bdl & bdl & bdl & bdl & na & na & bdl & bdl \\
\hline na & na & na & na & 0.03 & 0.07 & na & na & na & na & 0.06 & 0.04 & 0.04 & na \\
\hline 12.00 & 12.00 & 12.00 & 12.00 & 12.00 & 12.00 & 12.00 & 12.00 & 12.00 & 11.99 & 12.00 & 12.00 & 12.00 & 12.00 \\
\hline 0.02 & 0.01 & 0.01 & 0.04 & 0.00 & 0.46 & 0.04 & 0.12 & 0.54 & 0.58 & 0.15 & 0.37 & 0.01 & 0.89 \\
\hline 0.88 & 0.87 & 0.11 & 0.08 & 0.56 & 0.31 & 0.65 & 0.69 & 0.41 & 0.10 & 0.77 & 0.80 & 0.79 & 0.07 \\
\hline
\end{tabular}

prepared and petrographically studied, and X-ray diffractograms were obtained from pulverized parts of the samples. Those samples where the X-ray diffractograms and/or the petrographic characteristics indicated the presence of phases other than columbite/tantalite or cassiterite were analysed by scanning electronic microscopy (SEM) and preliminary electron microprobe analyses (EMPA) aiming to identify the unknown phases. This procedure resulted in the identification of several $\mathrm{Nb}-$ $\mathrm{Ta}-(\mathrm{Ti}-\mathrm{Sn})$ oxides that were previously unknown in the BPP, e.g. high-titanian ixiolite, fersmite, brannerite, strüverite, caesian natrobistantite or bismutomicrolite, plumbomicrolite, stibiomicrolite) and several new occurrences of ferrotapiolite, ferrowodginite and niobian rutile (Beurlen et al. 2003a, b, 2004, 2005). These findings were a clear indication that a systematic study of the $\mathrm{Nb}-\mathrm{Ta}-$
(Ti-Sn) oxides (and other "black ores") in the BPP is still of great interest. In the present paper, only data of the columbite, ixiolite, tapiolite, rutile and wodginite group minerals are considered.

The X-ray diffractograms were obtained using a D 5000 Siemens X-ray diffractometer and a $\mathrm{CuK} \alpha$ tube in the Department of Fundamental Chemistry of the Federal University of Pernambuco. Preliminary EMPA were obtained with a JEOL JXA 8600 in the EMPA laboratory of the University of São Paulo with the following operating conditions: $20 \mathrm{kV}, 40 \mathrm{nA}$ and acquisition times of $20 \mathrm{~s}$ for major, $30 \mathrm{~s}$ for minor and $40 \mathrm{~s}$ for trace elements. The following standards were used: $\mathrm{TiO}_{2} \mathrm{Ti}(\mathrm{Ti} K \alpha), \mathrm{Nb}$ $(\mathrm{NbL} \alpha), \mathrm{Ta}(\mathrm{TaM} \alpha), \operatorname{Sn}(\mathrm{SnL} \alpha)$, Anorthite $(\mathrm{AlK} \alpha)$, Olivine $(\mathrm{FeK} \alpha)$, Wollastonite $(\mathrm{CaK} \alpha)$, Spessartite $(\mathrm{MnK} \alpha)$ and $\mathrm{Bi}$ $(\mathrm{BiM} \alpha)$. 


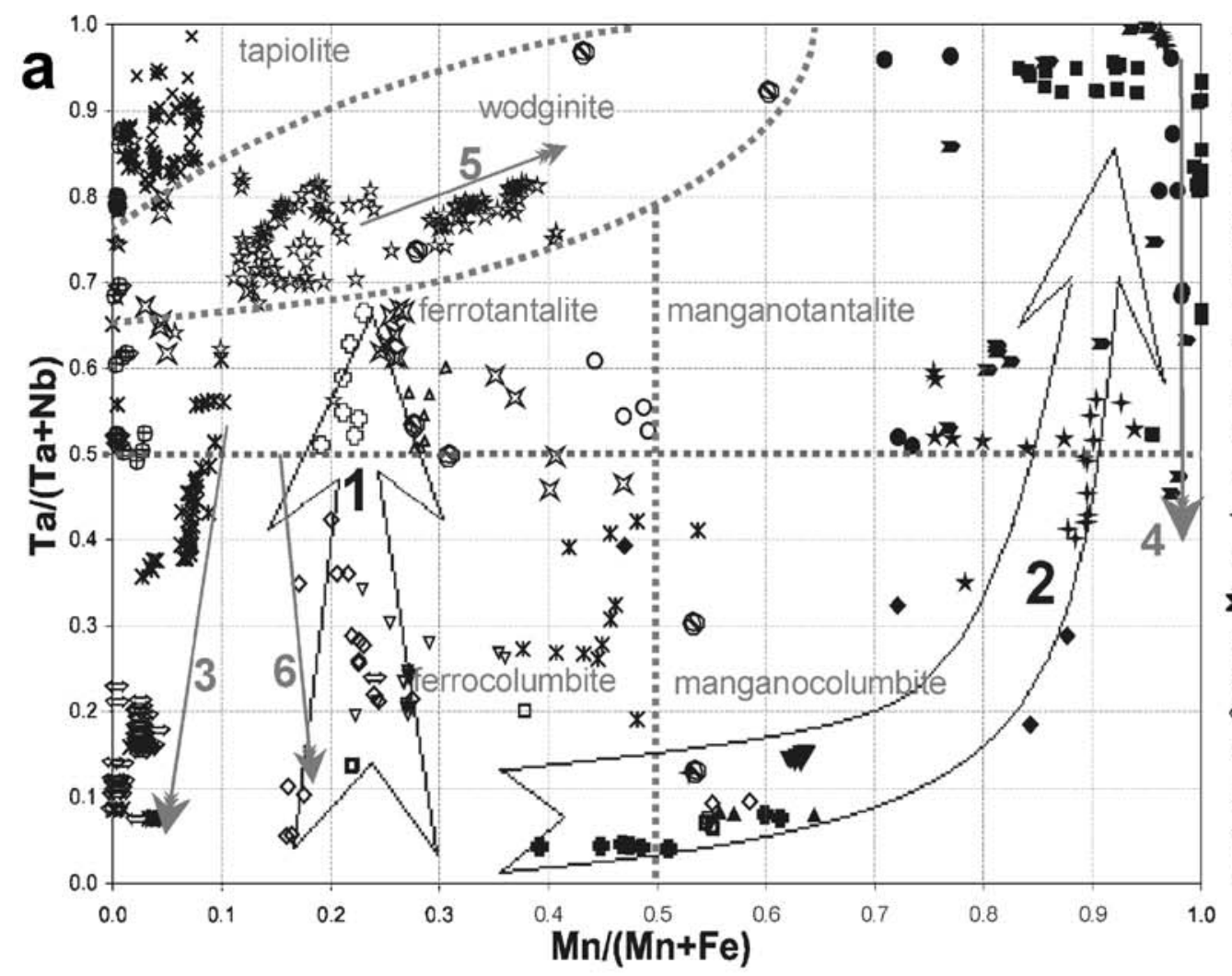

$\triangle$ Serraria

$\nabla$ Alto Feio

$\square$ Pitombeiras

$\checkmark$ Taboa

O Carcará

\ Roncadeira

Corredor

$\nabla$ Boqueirão 2

Giz, Amâncio

$\Delta$ Serraria 2

Quintos

- Caiçara

-Serra Branca

I Capoeira

$\checkmark$ Túneis

$\downarrow$ Cortume

$X$ Fe-Tapiolite

$\Leftrightarrow$ Nb-Rutile

$\oplus$ Strüverite

* Ixiolite

Wodginite

Q Previous

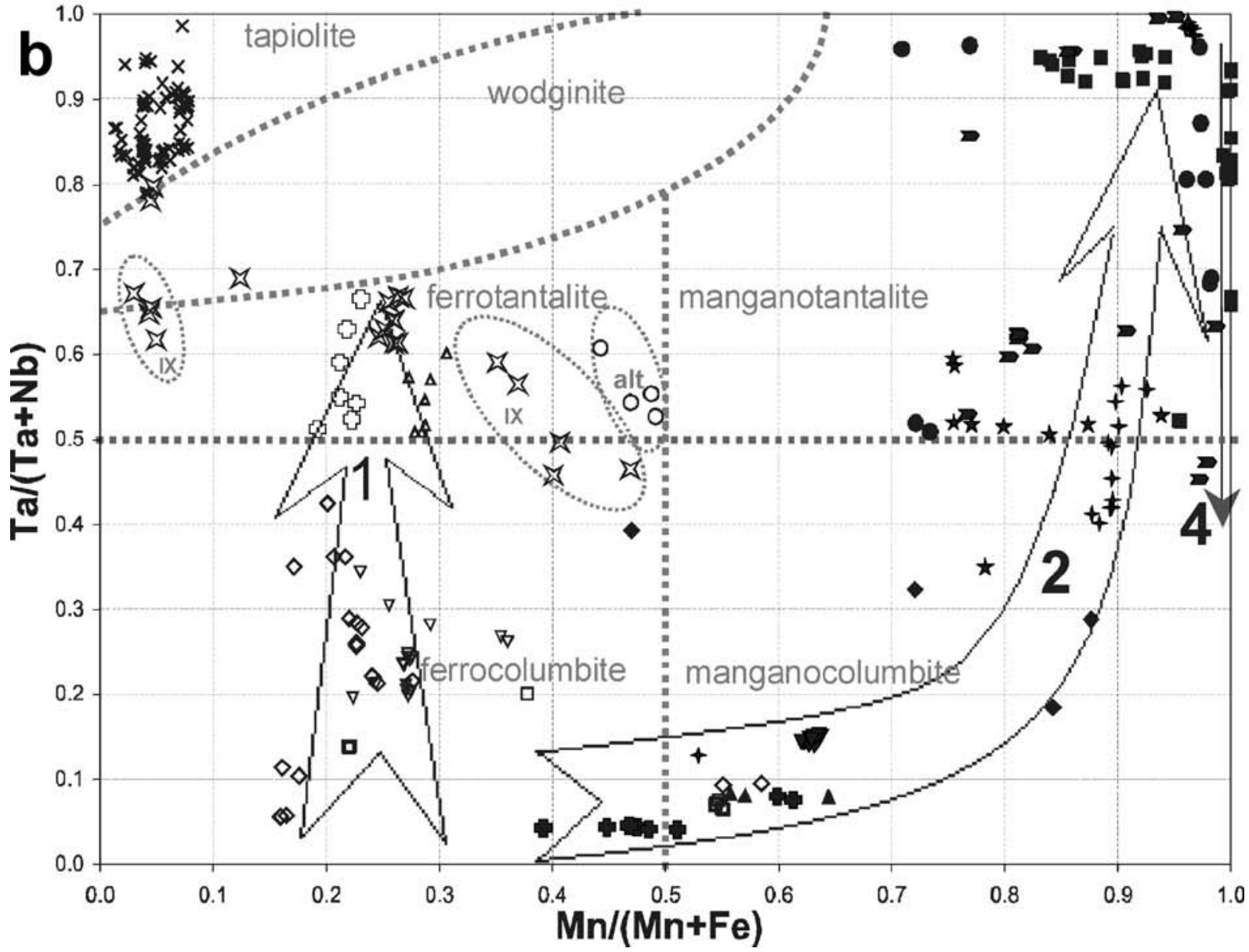


4 Fig. 5 a Columbite quadrilateral, binary plot of $\mathrm{Mn} /(\mathrm{Mn}+\mathrm{Fe})$ against $\mathrm{Ta} /(\mathrm{Ta}+\mathrm{Nb})$ APFU of more than 550 EMPA analyses of minerals from the columbite, tapiolite, ixiolite wodginite and rutile groups of the BPP. b After exclusion of most of the ixiolite and rutile group data, the following trends are outlined: Trends 1 and 2 correspond to the trends of beryl-columbite phosphate and spodumene and/or lepidolite subtype pegmatites, respectively (Černý 1989a, b). Additional, anomalous trends are defined by data of zoned crystals with late $\mathrm{Nb}$ and/or Ti and Fe enrichment at crystal borders (trend 3, ixiolilte from Quintos, trend 4, manganotantalite from Giz, Túneis and Branco and trend 6, ferrocolumbite from Pitombeiras). Trend 5 is defined by data of a zoned ferrowodginite crystal

Follow-up EMPA data were obtained at the GeoForschungsZentrum Potsdam, Germany, using a Cameca SX 50 and $\mathrm{SX} 100$ at $20 \mathrm{kV}$ and $40 \mathrm{nA}$, with acquisition times of $20 \mathrm{~s}$ for $\mathrm{Fe}(\mathrm{K} \alpha), \mathrm{Mn}(\mathrm{K} \alpha), \operatorname{Ti}(\mathrm{K} \alpha), \operatorname{Sc}(\mathrm{K} \alpha), \operatorname{Mg}(\mathrm{K} \alpha)$, $\mathrm{Al}(\mathrm{K} \alpha), \mathrm{Ca}(\mathrm{K} \alpha), \mathrm{Na}(\mathrm{K} \alpha), \mathrm{Si}(\mathrm{K} \alpha), \mathrm{K}(\mathrm{K} \alpha), 30 \mathrm{~s}$ for $\mathrm{Nb}$ $(\mathrm{L} \alpha), \mathrm{Sn}(\mathrm{L} \alpha), \mathrm{Sb}(\mathrm{L} \alpha), \mathrm{Zr}(\mathrm{L} \alpha), \mathrm{Hf}(\mathrm{M} \alpha), \mathrm{Y}(\mathrm{L} \alpha), \mathrm{Cs}$ $(\mathrm{L} \alpha), \mathrm{Ba}(\mathrm{L} \alpha)$ and $50 \mathrm{~s}$ for $\mathrm{Ta}(\mathrm{L} \alpha), \mathrm{Bi}(\mathrm{M} \alpha), \mathrm{U}(\mathrm{M} \alpha), \mathrm{Pb}$ $(\mathrm{M} \alpha)$, Th $(\mathrm{M} \alpha), \mathrm{Ce}(\mathrm{L} \alpha), \mathrm{La}(\mathrm{L} \alpha)$. The following standards were used: albite $(\mathrm{Na})$, ilmenite $(\mathrm{Fe}, \mathrm{Ti})$, cassiterite, orthoclase $(\mathrm{K}, \mathrm{Al})$, titanite $(\mathrm{Si}, \mathrm{Ca}, \mathrm{Ti}$,$) , zircon, \mathrm{Nb}, \mathrm{Ta}, \mathrm{Th}, \mathrm{U}$, vanadinite, $\mathrm{BaSO}_{4}, \mathrm{CePO}_{4}, \mathrm{LaPO}_{4}, \mathrm{YPO}_{4}, \mathrm{ScPO}_{4}, \mathrm{InSb}$, $\mathrm{MgO}, \mathrm{HfO}_{2}, \mathrm{MnTiO}_{3}, \mathrm{Bi}_{2} \mathrm{~S}_{3}$ and pollucite. Usually, only EMPA analyses with oxide weight percent totals between 102 and 98\% were used for interpretation, but the great majority of the data have totals between 99 and 101\%. In a few cases, data of particular interest were included even with totals in the range of $97-103 \%$.

The SEM analyses were obtained at the University of Campinas São Paulo using a SEM Leo 430i, Cambridge, EDS mod. Cat. B, using the following working conditions: $20 \mathrm{kV}, 30 \mathrm{~s}$ acquisition time, using the following standards: Ta $(\mathrm{Ta} \mathrm{M} \alpha), \mathrm{Nb}(\mathrm{Nb} \mathrm{L} \alpha), \operatorname{Sn}(\mathrm{Sn} \mathrm{L} \alpha), \mathrm{Ti}(\mathrm{Ti} \mathrm{K} \alpha)$, V (V $\mathrm{K} \alpha)$, Sb $(\operatorname{SbL} \alpha), \operatorname{Bi}(\operatorname{Bi} \mathrm{M} \alpha) \operatorname{Zr}(\mathrm{Zr} \operatorname{L} \alpha), \mathrm{U}(\mathrm{UM} \alpha), \mathrm{Hf}$ (Hf $\mathrm{M} \alpha), \mathrm{PbF}_{2}(\mathrm{PbM} \alpha), \mathrm{BCR} 2(\mathrm{Fe} \mathrm{K} \alpha, \mathrm{Mn} \mathrm{K} \alpha, \mathrm{Al} \mathrm{K} \alpha$, $\mathrm{Ca}(\mathrm{K} \alpha), \mathrm{Na}(\mathrm{K} \alpha), \mathrm{Si}(\mathrm{K} \alpha)$ and $\mathrm{K}(\mathrm{K} \alpha)$.

The calculation procedure to obtain the cationic composition in atoms per formula unit (APFU) listed in Tables 2 and 3 included in a first step the normalization of the data to a sum of 24 oxygen ions for most tantalates. In a second step, in cases where the obtained cation sum surpassed the corresponding theoretical value (12 cations for phases of the columbite, tapiolite and ixiolite groups and niobian rutile-strüverite, etc.), the $\mathrm{Fe}^{2+}$ content was partially converted to $\mathrm{Fe}^{3+}$ (according to Ercit et al. 1992c, d) by trial and error until the cation sum reached the value of $12.000 \pm 0.002$ cations. In the case of wodginite group minerals, the normalization was made recalculating $\mathrm{Fe}^{2+}$ to $\mathrm{Fe}^{3+}$ cations as much as necessary to complete the $\mathrm{B}+\mathrm{C}$ sites to 9.000 (for easier comparison with other minerals, for a 24-oxygen formula instead of the 32-oxygen formula required for the unit cell). The effectiveness of the $\mathrm{Fe}^{3+}$ correction procedure was checked by repeating some calculations using the method proposed by Droop (1987).

\section{Interpretation of the mineral chemistry data}

More than 550 EMPA data were transformed to APFU for 24-oxygen formulas according to the procedures described above. The commonly used atomic compositions and ratios were calculated and plotted on diagrams such as the 'columbite quadrilateral' and the ternary plots $(\mathrm{Nb}+\mathrm{Ta}) /$ $(\mathrm{Ti}+\mathrm{Sn}) /\left(\mathrm{Fe}^{*}+\mathrm{Mn}\right),(\mathrm{Ti}+\mathrm{Sn}) / \mathrm{Nb} / \mathrm{Ta}$ and $\mathrm{Ti} / \mathrm{Nb} / \mathrm{Ta}$. Selected representative data are listed in Tables 2 and 3.

The ternary plots do not display distinct fractionation trends for columbite group minerals. This is because these diagrams do not account for changes in the $\mathrm{Fe} / \mathrm{Mn}$ ratios. They are presented because they allow observation of eventual $\mathrm{Ti}$ and/or $\mathrm{Sn}$ trends in columbite and tapiolite group minerals and, in addition, a more precise distinction between ixiolite, wodginite and rutile group minerals, not shown in the columbite quadrilateral.

In the 'columbite quadrilateral' (Fig. 5a), the complete data set (excluding the pyrochlore group data) covers the entire range, and at first glance, the distribution apppears to be more or less chaotic. However, if the data of a few compositionally zoned columbite-tantalite crystals and wodginite, rutile and ixiolite are discarded, two main trends of columbite-tantalite compositions may be clearly visualized, as indicated by the arrows 1 and 2 in Fig. 5b. A few data located away from these two trends in Fig. $5 b$ refer to alteration products of ferrotapiolite (area identified as alt in Fig. 5b) and of ferrotantalite (identified as ix, including probable ixiolite and possibly a new mineral with a composition close to $\mathrm{Fe}^{3+} \mathrm{TaO}_{4}$ ) and not to crystals of primary origin.

The main trends 1 and 2 are similar to those identified by Černý (1989a, 1992) for the beryl-columbite phosphate (or F-poor spodumene subtype) and the lepidolite and/or spodumene (F-rich) subtype, respectively, of rare-element granitic pegmatites worldwide. Similar trends were distinguished as the 'ferroan' and 'manganoan' trends, respectively, in the Separation Rapids pegmatite field, northwestern Ontario, Canada (Tindle and Breaks 1998, 2000). Both trends begin with ferrocolumbite compositions for the apparently less fractionated pegmatites and evolve to ferrotantalite and local wodginite and ferrotapiolite (trend 1) and to manganocolumbite and manganotantalite (trend 2) for the more fractionated pegmatites. Both trends evolve with strong Ta enrichment, but only trend 2 shows also a distinct $\mathrm{Mn}$ enrichment, with increasing fractionation. The increase in the $\mathrm{Ta} /(\mathrm{Ta}+\mathrm{Nb})$ ratio with the evolution of pegmatite crystallization and/or with the degree of fractionation of the source magma can be explained by the lower 

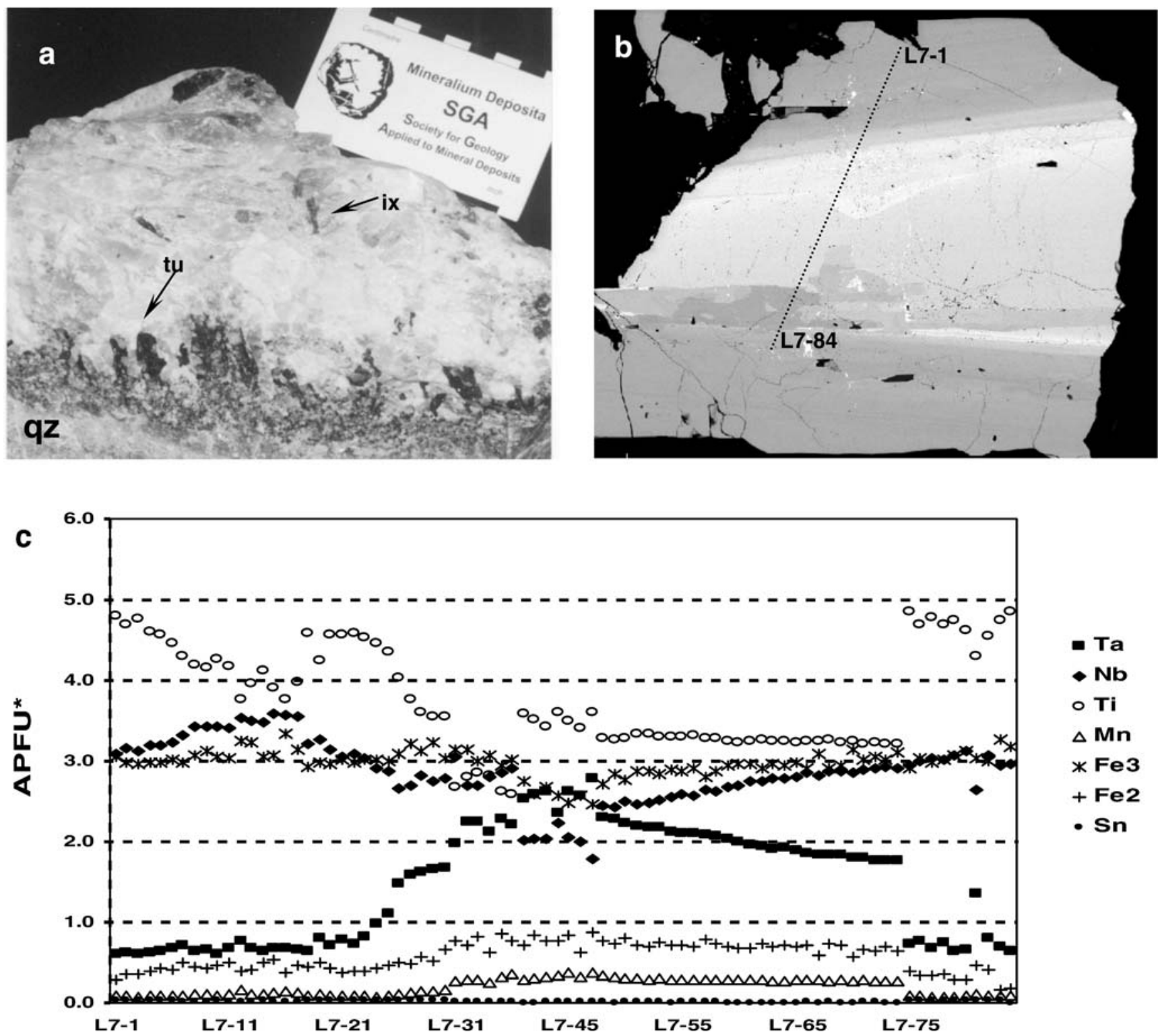

Fig. 6 a Sample of the contact of the Quintos pegmatite with quartzites $(q z)$. A comb-textured black tourmaline fringe (dravite, see arrow $t u$ ) marks the contact of the border zone with the wall zone, which contains sporadic millimetre-sized tabular, idiomorphic (thus primary), high-titanian ixiolite crystals (arrow ix). b SEM-BSEI of one of the high-titanian ixiolite crystals of the Quintos pegmatite, with oscillating compositional zoning (lighter zones, Ta rich and darker

zones, $\mathrm{Nb}$ or/and Ti rich) with niobian rutile borders; c EMPA crosssection of the same crystal as indicated in $\mathbf{b}$ (equidistance of $20 \mu \mathrm{m}$ ). Data in APFU for a 12-cation formula indicate a complex interaction of several alternating substitution mechanisms $(\mathrm{Nb} \leftrightarrow \mathrm{Ta}, \mathrm{Fe} \leftrightarrow \mathrm{Mn}$, $\left.2 \mathrm{Ti} \leftrightarrow \mathrm{Ta}+\mathrm{Fe}^{3+}, 2 \mathrm{Ti} \leftrightarrow \mathrm{Nb}+\mathrm{Fe}^{3+}, 3 \mathrm{Fe}^{3+} \leftrightarrow \mathrm{Ta}+2 \mathrm{Fe}, \mathrm{Mn}\right)$ or acting with oscillating intensity

solubility of Nb-rich columbite group members in peraluminous granite/pegmatite melts (Linnen and Keppler 1997) in comparison with Ta-rich members. In addition, the observation that the solubility of both $\mathrm{Ta}$ - and $\mathrm{Nb}$-rich members increases equally with temperature and F- and Li contents in the melt (Linnen 1998) is in agreement with the later crystallization of Ta-rich members, after the increase in the $\mathrm{Ta} / \mathrm{Nb}$ ratio in the melt because of the early columbite precipitation. This usually occurs at lower temperatures and when $\mathrm{Li}$ and $\mathrm{F}$ contents in the melt decreased during or after the formation of $\mathrm{Li}$ - and F-bearing minerals (e.g. spodumene, amblygonite, lithiophilite, lepidolite, elbaite), in the inner intermediate zone and/or in the replacement bodies of the pegmatites. The common association of Tarich ores with replacement bodies near the pegmatite core is known worldwide and was also recognized in the BPP (Da Silva et al. 1995). More difficult is the explanation of the increasing $\mathrm{Mn} /(\mathrm{Mn}+\mathrm{Fe})$ ratio with fractionation, as shown in trend 2 of Fig. 5b, and established for F-rich pegmatite subtypes elsewhere (Černý 1989a). The difficulty arises 


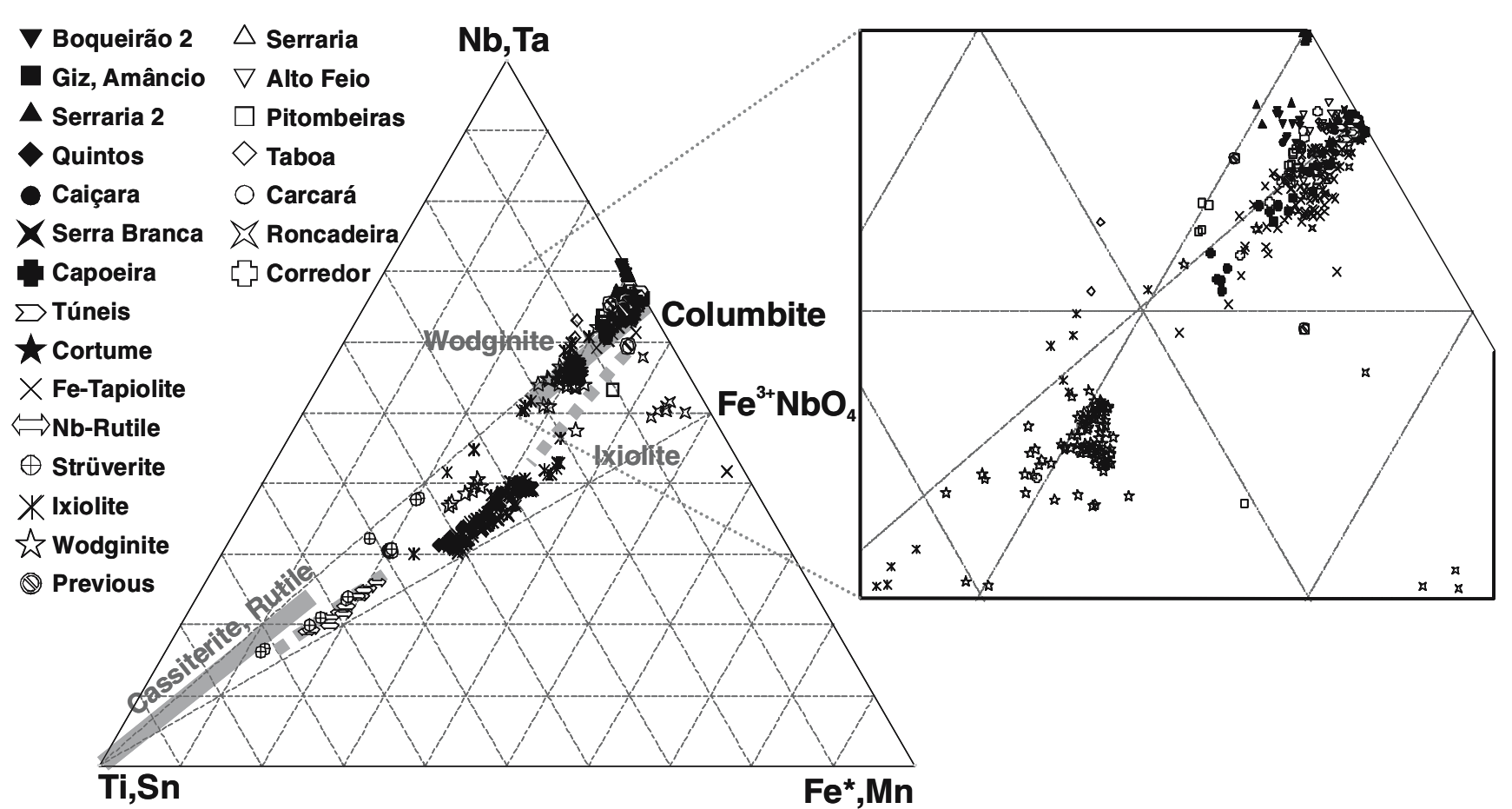

Fig. 7 Ternary $(\mathrm{Nb}+\mathrm{Ta}) /(\mathrm{Ti}+\mathrm{Sn}) /\left(\mathrm{Fe}^{(\text {total })}+\mathrm{Mn}\right)$ plot for the same EMPA data as in Fig. 5a. Two outstanding features are a series of ixiolite and niobian rutile data from the Quintos pegmatite filling the usually encountered gap between these coexisting phases on the $(\mathrm{Ti}$,

because the solubility of the Fe-rich members of the columbite group minerals in the melt is larger than that of Mn-rich members, according to Linnen (2004a, b). This fractionation trend must therefore be controlled by other Febearing minerals formed during the pegmatite evolution, such as tourmaline or biotite, according to London et al. (2001). In the BPP, the frequent occurrence of schorlite and Fe-rich Li phosphates in replacement bodies supports this argument. Unfortunately, our data are not yet sufficient to establish a statistical correlation of $\mathrm{Nb}-\mathrm{Ta}$ oxide mineral chemistry and variation of the modal composition along the different pegmatite zones.

The new results, even if based on only 28 of a total of more than 750 mineralized pegmatites in the BPP, indicate that at least two different subtypes of mineralized pegmatites of apparently different degree of fractionation may be distinguished in this province. The analytical data on $\mathrm{Nb}$ - $\mathrm{Ta}$ oxides from 22 of the 28 studied pegmatites are aligned along one of the two main trends identified (Fig. 5b). Data of the other six pegmatites can not be assigned to these trends because only tapiolite or ixiolite data are available.

Trend 1 in the BPP is based on data from the Corredor, Roncadeira, Feio, Serraria 1, Pitombeiras (1, 2 and 3), Canoa, Carcará and Taboa pegmatites, whereas trend 2 includes data from Boqueirão (1 and 2), Giz, Amâncio, Serraria 2, Quintos, Caiçara, Branco, Capoeira (1 and 2),
$\mathrm{Sn}) \mathrm{O}_{2}-\mathrm{Fe}^{3+} \mathrm{Nb}, \mathrm{TaO}_{4}$ tie line (space between the grey bars, dotted according to Uher et al. 1998 and straight line according to Černý et al. 1998) and a group of data close to the $\mathrm{Fe}^{3+} \mathrm{Nb}, \mathrm{TaO}_{4}$ end member

Túneis and Cortume (Fig. 5b). Because of the lack of a well-established model of a regional zonal distribution of different pegmatite subtypes in the BPP, it is not possible to verify if the difference in the $\mathrm{Fe} / \mathrm{Mn}$ behaviour in the two trends is related to the distance to a common source pluton. Such a zonal distribution of the two pegmatite groups could be related to the difference in the degree of fractionation, but the geographical distribution of pegmatites of both trends in the BPP overlaps and does not show a regular zonation pattern. The coincidence of the two main identified trends in pegmatites from the BPP with those established in the literature as representative for the berylcolumbite phosphate and complex spodumene subtype pegmatites, respectively (e.g. Černý 1989a, 1992; Tindle and Breaks 2000), indicates that the difference in the degree of fractionation could also be the most likely cause for the distinction of these two groups of BPP pegmatites. At least in two pegmatites, e.g. Quintos and Capoeira 2, other mineral chemistry data on feldspar, white mica, garnet, tourmaline and gahnite give additional support to this explanation (Soares 2004; Soares et al. 2007).

Otherwise, it is observed that pegmatites of trend 1 in the BPP are mainly hosted by biotite schists (six out of ten pegmatite bodies), whereas those of trend 2 (complex spodumene and/or lepidolite subtypes?) are preferentially hosted in quartzites and meta-conglomerates ( 8 out of 12 pegmatites). Because of this difference in host rocks, it 

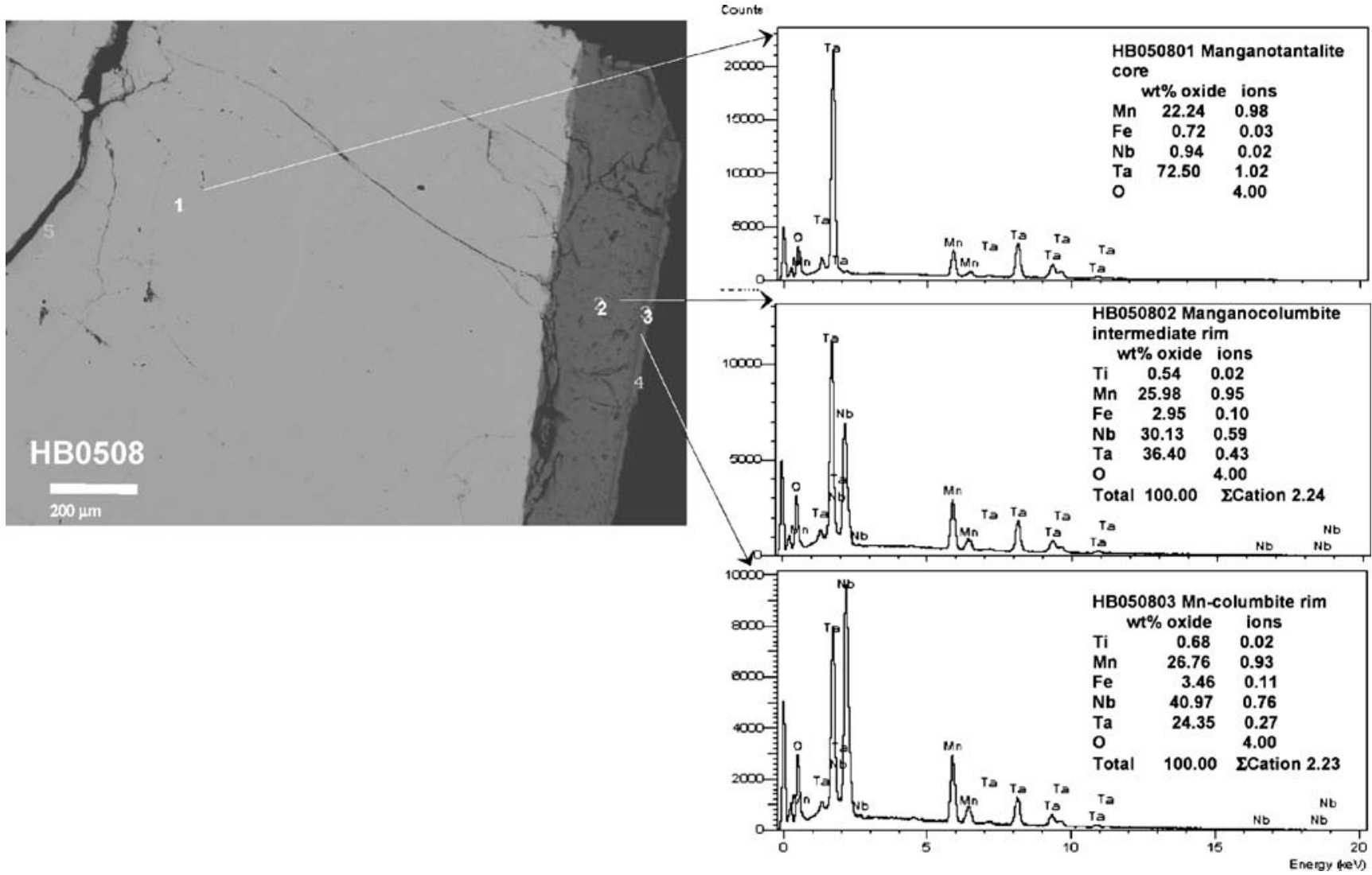

Fig. 8 a SEM-BSE image of a zoned manganotantalite crystal with a homogeneous core of manganotantalite with near end-member composition (frequently of gem quality, deep vine red colored), overgrown by a rim of manganocolumbite (usually opaque, black)

cannot be completely ruled out that the difference in the behaviour of $\mathrm{Fe}$ is in part influenced by interactions with the host rocks (e.g. Fe assimilation in pegmatites hosted by biotite schists).

Considering the remaining data, apart from trends 1 and 2 in Fig. 5a, three anomalous trends with strong $\mathrm{Nb}$ enrichment from core to rim of some zoned crystals are displayed by trends 3 (titanian ixiolite from the Quintos pegmatite), 4 (manganotantalite from Giz, Túneis, Giz and Brennand pegmatites) and 6 (ferrocolumbite from the Pitombeiras pegmatite). Trend 5 in Fig. 5a corresponds to ferrowodginite data from Fortuna, Corredor, Bento and Roncadeira pegmatites, including a zoned wodginite crystal (parallel to arrow 5) included in cassiterite of the Corredor pegmatite.

Trend 3 is exemplified by an EMPA section, with a data point equidistance of $20 \mu \mathrm{m}$, across one of several primary titanian ixiolite crystals collected in the wall zone of the Quintos pegmatite (Fig. 6a). This is a highly evolved/ fractionated pegmatite based on tourmaline and spinel mineral chemistry, trace-element ratios in feldspars and white micas (Soares 2004) and its mineralogy (rich in spodumene, lepidolite, gem quality elbaite and sporadic caesian bismutomicrolite or natrobistantite). The SEM- with oscillatory compositional growth zoning from the Branco pegmatite. b Semi-quantitative SEM analyses and spectra of the points indicated in a, representing an example of the reverse trend 4 in Fig. 5

backscattered electron image indicates an oscillating compositional zonation, with a general trend ranging from a Ta-rich core and a darker Ti-Nb-rich border (Fig. 6b). The EMPA (Fig. 6c) data confirm the oscillatory pattern of the zoning and present a general range from an ixiolite core with $\mathrm{Ta}>\mathrm{Nb}>\mathrm{Ti}$, to intermediate zones with increasing $\mathrm{Nb}-$ Ti contents $(\mathrm{Nb}>\mathrm{Ti}>\mathrm{Ta})$ and rims of niobian rutile $(\mathrm{Ti}>\mathrm{Nb}>$ Ta) compositions. A detailed observation of the EMPA section indicates a complex interaction of several substitution mechanisms like $\mathrm{Nb} \leftrightarrow \mathrm{Ta}, \mathrm{Fe} \leftrightarrow \mathrm{Mn}, 2 \mathrm{Ti} \leftrightarrow \mathrm{Ta}, \mathrm{Nb}+\mathrm{Fe}^{3+}$, $(\mathrm{Mn}, \mathrm{Fe})+2(\mathrm{Ta}, \mathrm{Nb}) \leftrightarrow 3 \mathrm{Ti}$, acting successively and/or with oscillatory intensity (Beurlen et al. 2003a). At the left part of the section (crystal), the compositional variation is gradual, whereas at the opposite part, a gap between the rutile border and the ixiolite phase in the core is observed. In the 'columbite quadrilateral,' the data follow an almost continuous rectilinear trend from $\mathrm{Mn} /\left(\mathrm{Mn}+\mathrm{Fe}^{*}\right)$ of 0.12 and $\mathrm{Ta} /$ $(\mathrm{Ta}+\mathrm{Nb})$ of 0.6 at the core to 0.01 and $0.12 \mathrm{APFU}$ at the rim, respectively. In this sample the distinction between ixiolite and columbite was made using the chemical criteria suggested by Wise et al. (1998).

Trend 3 in the ternary plot of $(\mathrm{Nb}+\mathrm{Ta}) /(\mathrm{Ti}+\mathrm{Sn}) /\left(\mathrm{Fe}^{*}+\right.$ Mn) (Fig. 7) is also rectilinear, very close to the 'tie line' 


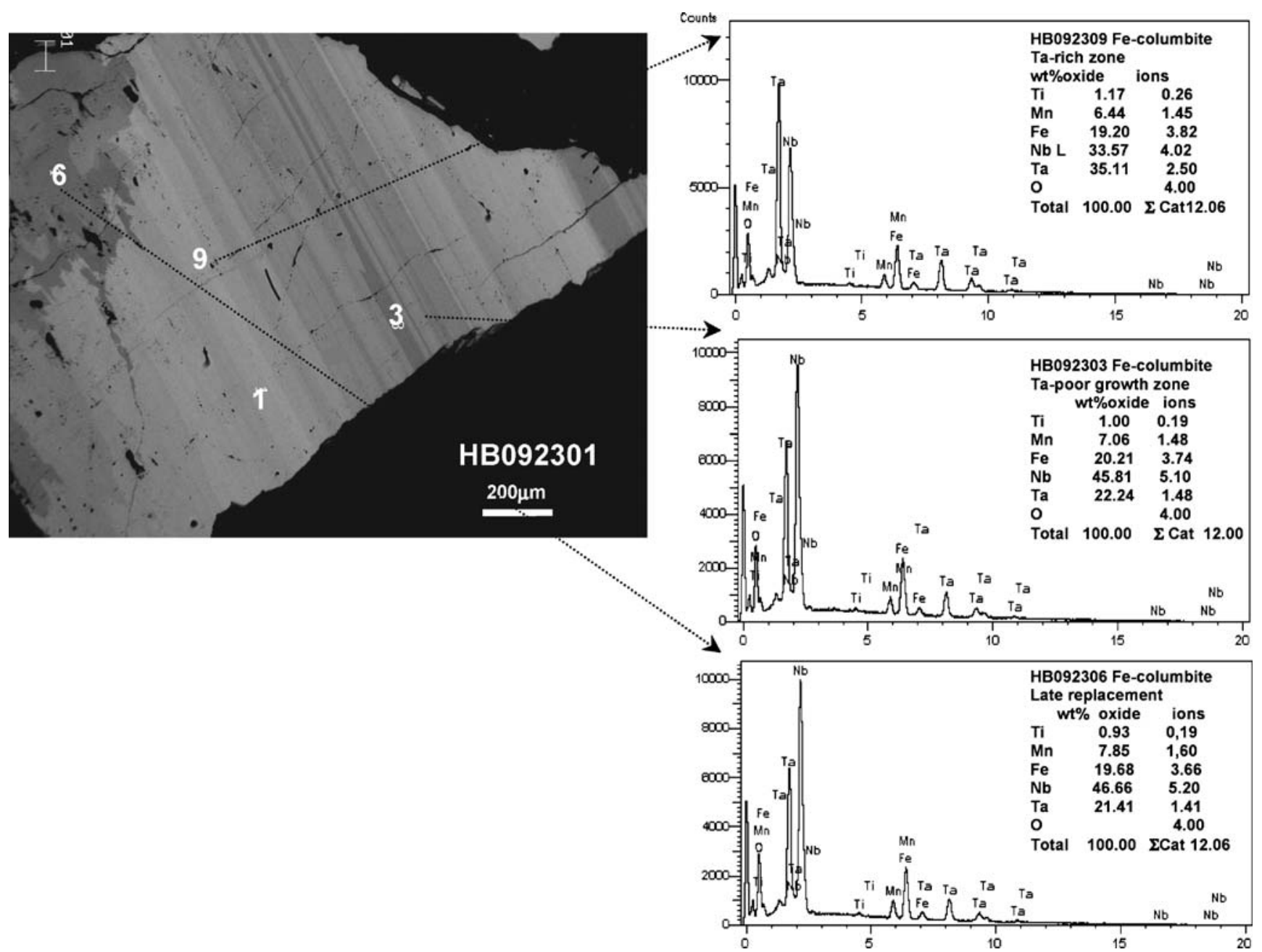

Fig. 9 SEM-BSE image of a ferrocolumbite crystal with oscillatory compositional growth zoning and peripheral replacement by a Nb-(+Ti)richer rim, corresponding to the reverse trend 6 in Fig. 5

between rutile and $\mathrm{Fe}^{3+}(\mathrm{Nb}, \mathrm{Ta}) \mathrm{O}_{4}$, indicating the presence of a high $\mathrm{Fe}^{+3} / \mathrm{Fe}^{+2}$ ratio, ranging from about 3 in the core and 6 in the intermediate zone to about 10 at the rim. The increasing proportion of $\mathrm{Fe}^{+3}$ from core to rim indicates increasing oxygen fugacity during crystal growth. The unusual compositional range of this trend fills the gap observed elsewhere between ixiolite and coexisting niobian rutile phases (Uher et al. 1998; Černý et al. 1998). The oscillatory nature of the zonation in these ixiolite crystals as demonstrated in Fig. $6 \mathrm{~b}$ and $6 \mathrm{c}$ is well shown only in diagrams that account for independent $\mathrm{Ti}, \mathrm{Nb}$ and $\mathrm{Ta}$ variations. A similar enrichment of $\mathrm{Ti}+\mathrm{Nb}+\mathrm{Fe}$ at the expense of $\mathrm{Ta}+\mathrm{Mn}$ from core to rim in $\mathrm{Nb}-\mathrm{Ta}-(\mathrm{Ti}-\mathrm{Sn})$ oxide crystals was recognized as a 'reverse trend' (Tindle and Breaks 1998) in comparison to the normal progressive $\mathrm{Ta}, \mathrm{Mn}$ enrichment ( $\mathrm{Nb}, \mathrm{Fe}$, Ti reduction) usually observed with increasing fractionation in wodginite (Tindle et al. 1998) and in columbite group minerals of the Separation Rapids pegmatite field (Tindle and Breaks 1998, 2000). This reverse trend is usually explained as a result of late replacement of former 'normal'-zoned primary tantalates during hydrothermal alteration or even metamorphism (Tindle and Breaks 2000; Černý et al. 1992). In the present case, the absence of the patchy intergrowths referred by these authors as typical of the late replacement and the simple planar limits observed between the growth zones, parallel to gradual changes in composition, appear to be in better agreement with a primary origin. A primary origin of these idiomorphic, tabular crystals is also indicated by their occurrence in the transition between the border and wall zone of the pegmatite and the absence of signs of hydrothermal alteration of the enveloping feldspar, muscovite and tourmaline grains.

Other high-titanian ixiolite data obtained from cuneiform, exsolution-like inclusions in niobian rutile host crystals from the Capoeira and Canoas pegmatites and from zoned ixiolite-ferrotantalite and titanowodginiteniobian rutile composite crystals from the Roncadeira and Feio pegmatites, respectively, do not form any particular trend, neither in the 'columbite quadrilateral' nor in the 


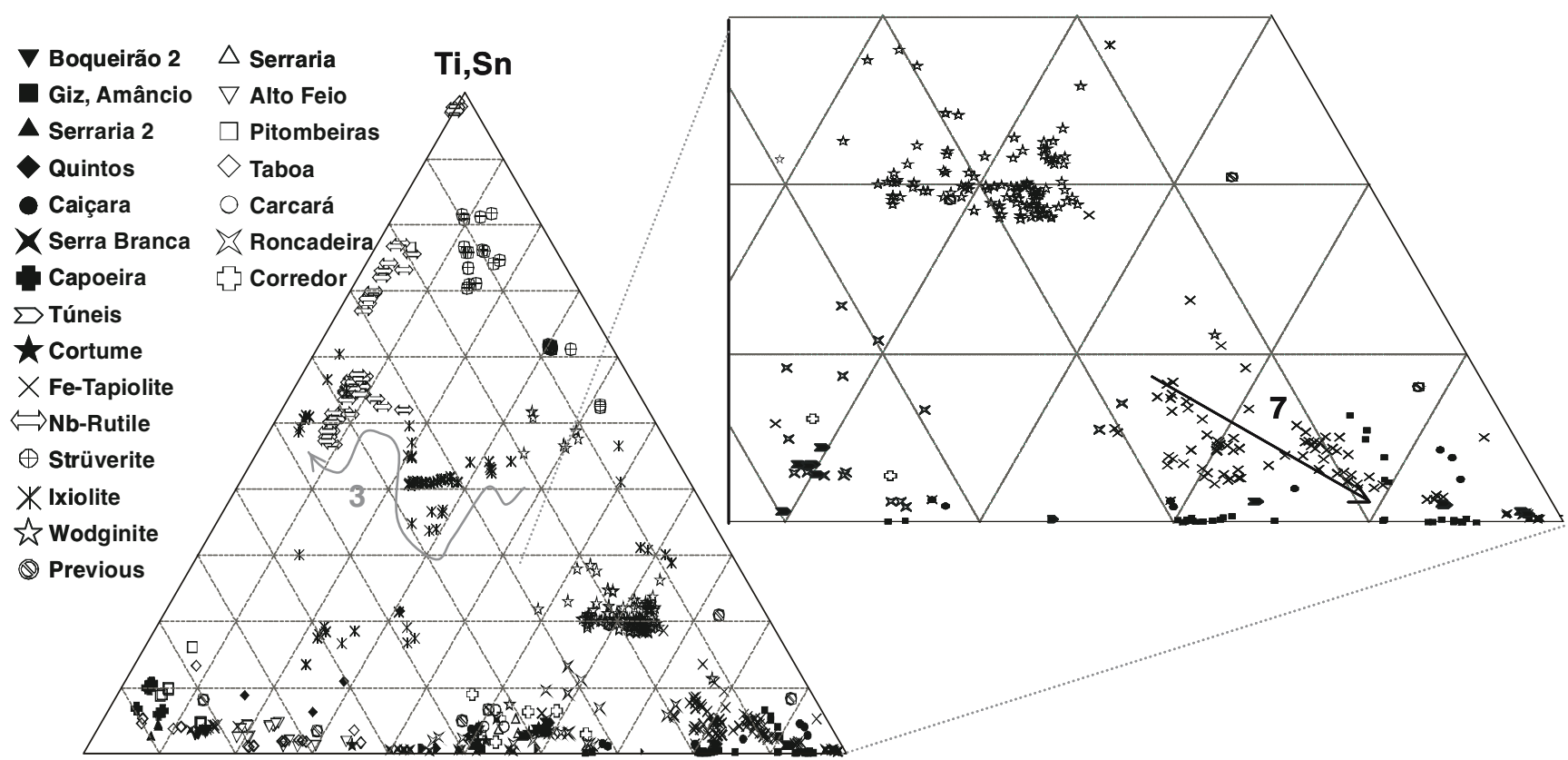

$\mathrm{Nb}$

Fig. $10(\mathrm{Ti}, \mathrm{Sn})-\mathrm{Nb}-\mathrm{Ta}$ ternary plot for the EMPA data shown in Fig. 5a. In addition to an easier distinction of ixiolite and wodginite group mineral phases, this diagram also allows the observation of the

ternary diagrams. The only common features of these ixiolite-rutile inter-growths are that the orthorhombic phases are always richer in $\mathrm{Nb}$ and $\mathrm{Mn}$ (and $\mathrm{Sc}, \mathrm{Zr}$ ) than the coexisting niobian rutile or strüverite hosts. This is in agreement with observations in other pegmatite fields worldwide (Černý et al. 1998) but contrasting with the

\section{$\mathrm{Ta}$}

oscillatory character of the high titanian ixiolite (trend 3, wavy line) of the Quintos pegmatite and a positive correlation of $\mathrm{Ti}$ and $\mathrm{Nb}$ in the tapiolite group minerals (trend 7 , in the inset)

atypical relation in the zoned crystal of the Quintos pegmatite (Ta enriched in ixiolite and depleted in coexisting rutile) described above (Fig. 6). An additional outstanding feature is that the compositional 'gaps' in ixiolite-rutile pairs observed so far in pegmatites from the BPP are very large in some cases (e.g. Canoas, Capoeira)

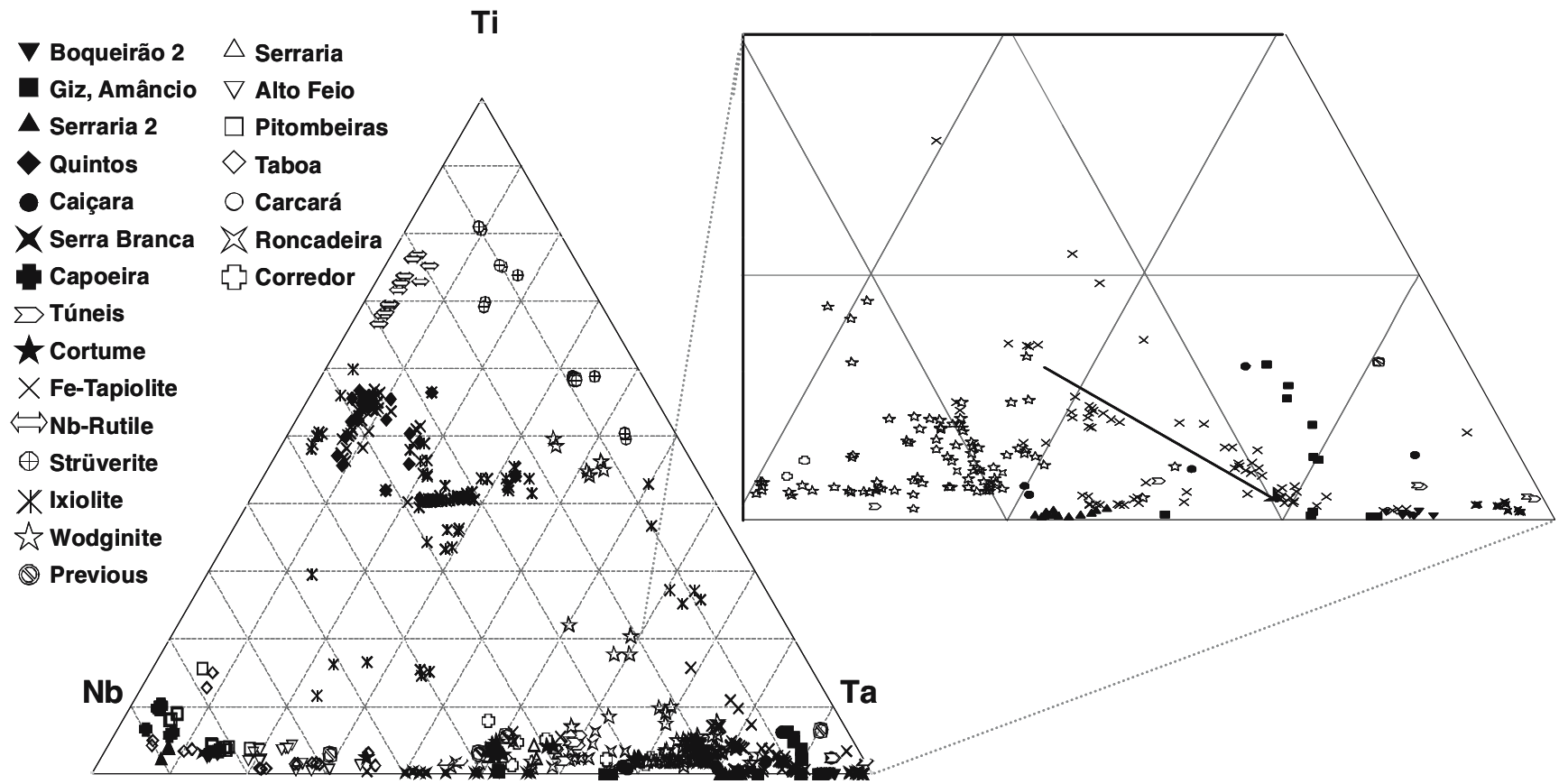

Fig. $11 \mathrm{Ti}-\mathrm{Nb}-\mathrm{Ta}$ ternary plot for the EMPA data shown in Fig. 5a. This plot in comparison to Fig. 10 confirms that trend 7 is due mainly to a variation in $\mathrm{Ti}$ contents rather than $\mathrm{Sn}$ 
but very small in others (e.g. Feio) and, in the case of the Quintos and Capoeiras pegmatites, form a 'quasi-continuum' (Fig. 7) in the area where compositional gaps are observed in data sets from other pegmatite provinces (Černý et al. 1998; Uher et al. 1998).

Trend 4 in the 'quadrilateral' (Fig. 5a) corresponds to a frequently observed black opaque $(\mathrm{Nb}$ rich with traces of Ti) border of gem quality, deep wine red, near end-member manganotantalite crystals (e.g. Giz, Amâncio, Brennand, Túneis and Mamões pegmatites). In most cases, this submillimetre- to millimetre-sized manganocolumbite border clearly replaces the large (centimetre-sized) homogeneous manganotantalite core, indicating the formation during a late hydrothermal, possibly secondary stage, as suggested from similar observations in other pegmatite provinces (Tindle and Breaks 2000; Černý et al. 1992; Tindle et al. 1998). In some crystals, however, these Nb-rich borders form an overgrowth with oscillatory compositional zoning (as shown in Fig. 8), suggesting a very late but still primary crystallization process.

Trend 6 (Fig. 5b) corresponds to one of several oscillatory-zoned ferrocolumbite grains (e.g. Fig. 9) of an ilmenite-rich pan concentrate from the Pitombeira pegmatite. A general 'reverse trend' is also observed, with $\mathrm{Nb}$ enrichment from core to $\operatorname{rim}(\mathrm{Ta} /(\mathrm{Ta}+\mathrm{Nb})$ ranging from 0.38 to $0.21 \mathrm{APFU}$, whereas the $\mathrm{Fe} /(\mathrm{Fe}+\mathrm{Mn})$ ratio remains nearly constant between 0.28 and 0.30 APFU.

Trend 5 (Fig. 5a) is a normal trend observed in some millimetre-sized ferrowodginite inclusions in cassiterite collected in the border zone of the Corredor pegmatite, with progressive $\mathrm{Ta}$ and $\mathrm{Mn}$ enrichment from core to rim, together with reduction in small contents in Ti. In some cassiterite ('pseudostaringite') crystals, a primary compositional zoning was also preserved, now defined by variations in frequency and type of fine (micrometer sized) to ultrafine sub-microscopic $(0.1 \mu \mathrm{m}$ or less $)$ exsolutions, with lamellar columbite exsolutions in the core (thus $\mathrm{Nb}$ saturated cassiterite host) and emulsion-like ferrowodginite exsolutions at the rim (thus Ta-saturated, Beurlen et al. 2004). It is remarkable that in other samples of the border zone of the same pegmatite, a reverse trend is observed in idiomorphic crystals with ferrotantalite cores, enveloped by a Ti-Nb-rich rim of ixiolite (electron diffraction analyses in a high resolution transmission electron microscope confirmed the phase determination, using the FIB sampling method described by Wirth (2004)).

Another trend, formed by the tapiolite data (trend 7 in Figs. 10 and 11), is not visible in the 'quadrilateral' (Fig. 5) but indicates a positive correlation between $\mathrm{Ti}+\mathrm{Sn}$ and $\mathrm{Nb}$. The latter may be used as a tracer for the degree of fractionation, which apparently increases with decreasing contents in $\mathrm{Ti}, \mathrm{Sn}$ and $\mathrm{Nb}$ and increase in Ta. More data are needed to confirm this possibility.
Besides the interpretations of the compositional variations of columbite-ixiolite and rutile-wodginite group phases, some EMPA data obtained in small irregular shaped inclusions along cleavage planes and fractures in ferrocolumbite from the Roncadeira pegmatite are preliminarily identified as 'titanian ferrotantalite.' They have a composition that is very close to the $\mathrm{Fe}^{+3}(\mathrm{Ta}, \mathrm{Nb}) \mathrm{O}_{4}$ end member, shown in Fig. 7. This composition is presently unknown as a natural mineral. There is no possibility to assign a columbite or tapiolite group formula to these data because the observed total iron exceeds the required $0.5(\mathrm{Fe}+\mathrm{Mn}) /$ $(\mathrm{Ta}+\mathrm{Nb})$ ratio. The observed $\left(\mathrm{Fe}^{2+}+\mathrm{Fe}^{3+}+\mathrm{Mn}+\mathrm{Ti}+\mathrm{Sn}+\right.$ $\mathrm{Sc}) /(\mathrm{Ta}+\mathrm{Nb})$ ratio is indeed near to 1.0 and would allow to propose a 'ferri-ferri-wodginite'-like formula according to the wodginite group nomenclature (Ercit et al. 1992d), with $\mathrm{Fe}^{3+}$ dominating both the $\mathrm{A}$ and $\mathrm{B}$ sites (in the general $\mathrm{ABC}_{2} \mathrm{O}_{8}$ formula), or a disordered 'ferri-ixiolite' formula. Because of the small size of the inclusions, it is not possible to obtain diffractometric results.

The identification of complex spodumene subtype pegmatites in the BPP based on the compositional variation in columbite group minerals (trend 2) as proposed here is of economic importance because according to Černý (1989a, 1992) only the lepidolite/spodumene/ petalite/amblygonite-subtype pegmatites may reach economic grades of Ta ores. This is in contrast to the Separation Rapids pegmatite field (northwestern Ontario, Canada) where Ta- and Li-ore grades were observed in highly fractionated pegmatite bodies of the 'ferroan trend' (Tindle and Breaks 2000), with $\mathrm{Ta} /(\mathrm{Ta}+\mathrm{Nb})$ ratios ranges falling along the same trend that are established for the beryl-columbite phosphate subtype pegmatites by Černý (op. cit.).

\section{Conclusions}

The EMPA data so far obtained on $\mathrm{Nb}-\mathrm{Ta}-\mathrm{Sn}-\mathrm{Ti}$ oxides (excluding pyrochlore group minerals) from 28 different pegmatites of the BPP exhibit, at first glance, an apparently chaotic distribution in the tantalite-columbite group 'quadrilateral.'

This complex scenario is the result of the superposition of many erratic data, a few distinct anomalous trends outlined by single-zoned crystal data obtained on ixiolite, wodginite, manganotantalite and ferrotantalite samples, which overlap and camouflage the two main trends, outlined by the majority of data of the columbite group minerals of several pegmatites. The anomalous trends are explained by the overall decrease in the $\mathrm{Ta} / \mathrm{Nb}$ ratio from core to rim of zoned crystals, in contrast to the 'normal' Ta enrichment with increasing fractionation. In many cases where oscillatory compositional-zoning patterns are ob- 
served, it is proposed that these result mostly from disequilibrium conditions during crystallization.

The two 'normal' trends in Fig. 5b nearly match the trends of beryl-type, beryl-columbite phosphate-subtype (and/or F-poor complex spodumene subtype) and complex lepidolite and/or F-rich spodumene-subtype pegmatites recognized elsewhere by Černý $(1989 a, 1992)$ or the ferroan and manganoan trends found in the Separation Rapids pegmatite field in northwestern Ontario, Canada (Tindle et al. 1998; Tindle and Breaks 2000). These results indicate the existence of, at least, two distinct subtypes of mineralized rare-element granitic pegmatites in the BPP. They also indicate a much more evolved degree of fractionation for many pegmatites in the BPP (e.g. those of trend 2), than earlier suggested by Da Silva et al. (1995), who classified the BPP pegmatites as belonging to the beryl-columbite phosphate subtype, based mainly on feldspar and mica chemistry. The evidence that higher degrees of fractionation were reached in the BPP agrees with geochemical data obtained on white micas, garnets, tourmaline and gahnite (Soares 2004) and the widespread occurrence of primary $\mathrm{Nb}-\mathrm{Ta}$ oxide minerals, which are typical of pegmatites with a high degree of fractionation (e.g. end-member manganotantalite, simpsonite, several microlite subgroup species, stibio- and bismutotantalite). Because of scarce geochronological data, it is still an open question if these two pegmatite (sub-) types are of the same age and originate from the same, still unknown but likely granitic, source. Some field evidence indicates that some highly fractionated (second-stage) pegmatites may have formed from magmas generated from previous pegmatites before their complete crystallization (Figs. 3b,c).

The presence of anomalous, 'reverse' trends with latestage $\mathrm{Nb}-\mathrm{Fe}-\mathrm{Sn}-\mathrm{Ti}$ enrichment, also observed in other pegmatite provinces (Tindle et al. 1998; Smeds et al. 1999; Černý et al. 2004), is usually considered the result of late, subsolidus, hydrothermal alteration, partially replacing primary crystals, or the result of pegmatite/wall rock interaction. In the BPP, some cases present textures strongly suggestive of a primary nature of these anomalous trends (e.g. primary crystals with gradual oscillatory compositional variations parallel to crystallographic planes). In other cases, textures clearly indicate late replacement processes. However, there are no observations in the BPP to support pegmatite/wall rock interaction as the cause for the frequently observed primary or late $\mathrm{Ti}-\mathrm{Fe}$ enrichment of $\mathrm{Nb}-\mathrm{Ta}$ oxides, as suggested elsewhere based on the correlation with mafic host rocks (Černý and Nemec 1995; Uher and Broska 1995).

Independent of the origin, the frequent observation of anomalous trends in single $\mathrm{Nb}-\mathrm{Ta}$ oxide crystals and the compositional variation between samples from different zones in the pegmatites in the BPP indicate that for routine exploration purposes, the mineral chemistry of $\mathrm{Nb}-\mathrm{Ta}$ oxides would be of diagnostic value only if a large data set of representative samples (heavy mineral concentrates rather than isolated crystals), systematically collected parallel to pegmatite cross-sections, is available. Because of this complex sampling procedure, the use of the $\mathrm{Nb}-\mathrm{Ta}$ oxide chemistry as an exploration tool would likely be more difficult and more expensive than using other much more frequent accessory minerals such as garnet, spinel and tourmaline, which are less susceptible to alteration.However, $\mathrm{Nb}-\mathrm{Ta}$ oxide chemistry can provide additional key information for a metallogenetic/petrogenetic understanding.

This first study of the $\mathrm{Nb}-\mathrm{Ta}-(\mathrm{Ti}-\mathrm{Sn})$ oxide mineral chemistry on pegmatites from the BPP opens new perspectives on the metallogenetic potential of this province. The possibility of undiscovered $\mathrm{Li}$ - and/or Cs-rich ores and larger and higher-grade Ta ore reserves must be seriously considered, and more detailed research work is necessary in the BPP.

Acknowledgements This study became possible because of financial support of the Brazilian Research Council-CNPq, through grants APQ 470199/01 e PQ 352181/92-3 and by CAPES (grant AEX 0728/ 04-7). We are also indebted to Prof. W. Heinrich of the GeoForschungsZentrum Potsdam (GFZ) in Germany for the free use of the Microprobe facility, to O. Appelt and G. Rhede of the GFZ for the technical support during the microprobe analyses, to Prof. Bernardino R. Figueiredo of the Instituto de Geociencias of the University of Campinas, Brazil (IGE-UNICAMP), for authorization and Dailto Silva for the SEM analyses at the IGE-UNICAMP. We thank Claudio de Castro (Federal University of Pernambuco, Brazil-UFPE) for providing several samples for this study. Two anonymous reviewers and David London (University of Oklahoma, School of Geology and Geophisics), Steffen Hagemann (University of Western Australia, Centre for Exploration Targeting) and Gorki Mariano and Ignez P. Guimarães (UFPE) are greatly acknowledged for critical reading and very helpful and constructive discussion.

\section{References}

Adusumili MPS (1978) Nióbio-tantalatos do Nordeste do Brasil: a série columbita-tantalita. J Mineral 7:195-225

Almeida FFM, Melcher GC, Cordani UG, Kawashita K, Vandoros P (1968) Radiometric age determinations from Northern Brazil. São Paulo. Soc Bras Geol Bol 17:3-15

Araújo MNC, Silva FCA, Jardim de Sá EF (2001) Pegmatite emplacement in the Seridó Belt, Northeaster Brazil: late stage tectonics of the Brasiliano Orogen. Gondwana Res 4:75-85

Araújo MNC, Vasconcelos PM, Silva FCA, Jardim de Sá EF, Sá JM (2005) $40 \mathrm{Ar} / 39 \mathrm{Ar}$ geochronology of gold mineralization in Brasiliano strike-slip shear zones in the Borborema province, NE Brazil. J South Am Earth Sci 19:445-460

Baumgartner R, Moritz R, Romer R, Sallet R (2001) Mineralogy and $\mathrm{U}-\mathrm{Pb}$ geochronology of beryl and columbo-tantalite pegmatites in the Serido pegmatite district, northeastern Brazil. In: Piestrzynski A et al. (eds) Mineral deposits at the beginning of the 21st century, Proceedings of the 6th biennial SGA meeting, Krakow, Poland, 26-29 August 2001, Balkema Rotterdam, pp 371-375 
Baumgartner R, Moritz R, Romer R, Sallet R (2006) Mineralogy and $\mathrm{U}-\mathrm{Pb}$ geochronology of beryl and columbo-tantalite pegmatites in the Serido pegmatite district, northeastern Brazil. Can Mineral 44:69-86

Beurlen H, Soares DR, Prado-Borges LE, Da Silva MRR (2003a) Análise de mecanismos de substituição em tantalato exótico : provável titano-ixiolita na Província Pegamtítica da Borborema. Rev Geol (UFCE) 16(2):7-18

Beurlen H, Thomas R, Barreto SB, Da Silva MRR (2003b) Nova ocorrência de ferrowodginita em associação com cassiterita, strüverita e tapiolita na Província Pegmatítica da Borborema, Nordeste do Brasil. Est Geol 13:35-45

Beurlen H, Castro C, Thomas R, Da Silva MRR, Prado-Borges LE (2004) Strüverite and Scandium bearing titanian ixiolite from the Canoas Pegmatite (Acari-Rio Grande Do Norte) in the Borborema Pegmatitic Province, Ne-Brazil. Est Geol 14:20-31

Beurlen H, Soares DR, Thomas R, Prado-Borges LE, Castro C (2005) Mineral chemistry of tantalate species new in the Borborema Pegmatitic Province, Northeast Brazil. An Acad Bras Ciênc 77:169-182

Brasil (1998) Mapa geológico do Estado do Rio Grande do Norte. DNPM-CPRM/UFRN, Brasil

Brasil (2002) Mapa geológico do Estado da Paraíba. DNPM-CPRM/ CDRM, Brasil

Burke EAJ, Kieft C, Ofelius R, Adusumili MPS (1969) Staringite, a new Sn-Ta mineral from north-eastern Brazil. Mineral Mag 37:447-452

Burke EAJ, Kieft C, Ofelius R, Adusumili MPS (1970) Wodginite from Northeastern Brazil. Geol Mijnb 49:235-240

Cameron EM, Jahns RH, Mc Nair H, Page LR (1949) Internal structure of granitic pegmatites. Econ Geol Monogr 2:115 p

Černý P (1989a) Characteristics of pegmatite deposits of tantalum. In: Moeller P, Černý P, Saupé F (eds) Lantanides, tantalum, niobium. Springer, Berlin Heidelberg New York, pp 195-235

Černý P (1989b) Exploration strategy and methods for pegmatite deposits of tantalum. In: Moeller P, Černý P, Saupé F (eds) Lantanides, tantalum, niobium. Springer, Berlin Heidelberg New York, pp 274-302

Černý P (1991) Rare element granitic pegmatites. Part 1: anatomy and internal evolution of pegmatite deposits. Geosci Can 18:49-67

Černý P (1992) Geochemical and petrogenetic features of mineralization in rare-element granitic pegmatites in the light of current research. Appl Geochem 7(5):393-416

Černý P (1998) Magmatic vs metamorphic derivation of rare-element granitic pegmatites. Krystalinikum 24:7-36

Černý P, Ercit TS (1985) Some recent advances in the mineralogy and geochemistry of $\mathrm{Nb}$ and $\mathrm{Ta}$ in rare-element granitic pegmatites. Bull Mineral 108:499-532

Černý P, Ercit TS (1989) Mineralogy of Niobium and Tantalum: crystal chemical relationships, paragenetic aspects and their implications. In: Moeller P, Černý P, Saupé F (eds) Lantanides, tantalum, niobium. Springer, Berlin Heidelberg New York, pp 27-79

Černý P, Nemec (1995) Pristine vs. contaminated trends in Nb,Taoxide minerals of the Jihlava pegamatite District, Czech Republic. Mineral Petrol 55:117-129

Černý P, Novak M, Chapman P (1992) Effects of sillimanite-grade metamorphism and shearing on $\mathrm{Nb}$-Ta-oxide minerals in granite pegmatites: Marsikov, Northern Moravia., Czechoslovakia. Can Mineral 30:699-718

Černý P, Ercit TS, Wise MA, Chapman R, Buck, HM (1998) Compositional structural and phase relationships in titanian ixiolite and titanian columbite-tantalite. Can Mineral 36:547562

Černý P, Chapman R, Ferreira K, Smeds S (2004) Geochemistry of oxide minerals of $\mathrm{Nb}, \mathrm{Ta}, \mathrm{Sn}$ and $\mathrm{Sb}$ in the Varuträsk granitic pegmatite, Sweden: the case of an anomalous columbite-tantalite trend. Am Mineral 89:505-518

Cunha e Silva J (1981) Formação polimetalífera da região da Borborema, Estados do RioGrande do Norte e Paríba. CPRM, Recife, 135 pp

Cunha e Silva J (1983) Zonação polimetalífera da Região da Borborema, Estado do Rio Grande do Norte e Paraiba. Mineração e Metalurgia 47(445):24-36

Da Silva MRR (1993) Petrographical and geochemical investigations of pegmatites in the Borborema Pegmatitic province of Northeastern Brasil. Thesis, Ludw. Max. University, München, 306 pp

Da Silva MRR, Höll R, Beurlen H (1995) Borborema Pegmatitic Province: geological and geochemical characteristics. J South Am Earth Sci 8:355-364

Droop GTR (1987) A general equation for estimating $\mathrm{Fe}^{3+}$ concentrations in ferromagnesian silicates and oxides from microprobe analyses using stoichiometric criteria. Mineral Mag $51: 431-435$

Ebert H (1969) Geologia do Alto Seridó. Recife, Brazil. SUDENE Serie Geol Reg 11:120

Ebert H (1970) The Precambrian geology of the "Borborema" belt (States of Paraíba and Rio Grande do Norte) and the origin of its mineral provinces. Int J Earth Sci 59:1292-1326

Ercit TS, Hawthorne FC, Černý P (1985) The crystal structure of synthetic natrotantite. Bull Mineral 108:541-549

Ercit TS, Hawthorne FC, Černý P (1986) Parabariomicrolite, a new species and its structural relationship to the pyrochlore group. Can Mineral 24:655-663

Ercit TS, Hawthorne FC, Černý P (1992a) The crystal structure of alumotantite its relations to the structure of simpsonite and the $(\mathrm{AlGa})(\mathrm{TaNb}) \mathrm{O} 4$ compounds. Can Mineral 30:653-662

Ercit TS, Černý P, Hawthorne FC (1992b) The crystal chemistry of simpsonite. Can Mineral 30:663-672

Ercit TS, Černý P, Hawthorne FC, Mc Cammon CA (1992c) The wodginite group II: crystal chemistry. Can Mineral 30:613-632

Ercit TS, Černý P, Hawthorne FC (1992d) The wodginite group III: classification and new species. Can Mineral 30:633-638

Jardim de Sá EF (1994) A Faixa Seridó (Província Borborema, NE do Brasil) e seu significado geodinâmico na cadeia Brasiliana/ Panafricana. Ph.D. thesis, UnB, Brazil, 762 pp

Jardim de Sá EF, Legrand JM, McReath I (1981) Estratigrafia de rochas granitóides na Região do Seridó (RN-PB) com base em critérios estruturais. Rev Bras Geocienc 11:50-57

Jardim de Sá EF, Legrand JM, Galindo AC, Hackspacker PC (1986) Granitogênese Brasiliana no Seridó: o maciço de Acari (RN). Rev Bras Geocienc 16:95-105

Johnston WD (1945) Beryl-tantalite pegmatites of Northeastern Brazil. Geol Soc Amer Bull 56:1015-1070

Kretz R (1983) Symbols for rock-forming minerals. Am Mineral 68:277-279

Legrand JM, Deutsch S, Souza LC (1991) Datação U/Pb e granitogênese do maciço Acari (RN). In: SBG $14^{\circ}$ Simp. Geol. Nordeste Atas Bol, vol 12, pp 172-174

Lima ES (1986) Metamorphism and tectonic evolution in the Seridó Region, Northeastern Brazil. Ph.D. thesis, Univ. of California Los Angeles, Los Angeles, CA, $215 \mathrm{pp}$

Linnen RL (1998) The solubility of Nb-Ta-Zr-Hf-W in granitic melts with $\mathrm{Li}+\mathrm{F}$ : constraints for mineralization in rare metal granites and pegmatites. Econ Geol 93:1013-1025

Linnen RL (2004a) PIG comments and questions, reply. http://www. minsocam.org/MSA/Special/Pig/Pig_CQ/PIG_CQ/Kjellman.html

Linnen RL (2004b) Ferrocolumbite-manganotantalite trends in granites and pegmatites: experimental and natural constraints. Geol Soc Amer Progr Abstr 36

Linnen RL, Keppler H (1997) Columbite stability in granitic melts: consequences for the enrichment and fractionation of $\mathrm{Nb}$ and $\mathrm{Ta}$ in the earths crust. Contrib Mineral Petrol 128:213-227 
London D (1992) The application of experimental petrology to the genesis and crystallization of granitic pegmatites. Can Mineral 30:440-499

London D (1996) Granitic pegmatites. Trans R Soc Edinb Earth Sci 87:305-319

London D (2005) Granitic pegmatites: an assessment of current concepts and directions for the future. Lithos 80:281-303

London D, Evensen JM, Fritz E, Icenhower JP, Morgan GB, Wolf MB (2001) Enrichment and accommodation of manganese in granitepegmatite systems. 11th An. Goldschmidt Conf Abstr 3369. CDR PDF version

Magyar MJ (2007) Tantalum. In: Commodity Summaries 2007, US Geol Survey, pp 164-165

Morteani G, Preinfalk C, Horn AC (2000) Classification and mineralization potencial of the pegmatites of the Eastern Brazilian Pegmatite Province. Miner Deposit 35:638-655

Pough MW (1945) Simpsonite and the Northern Brazilian pegmatite region. Bull Geol Soc Am 56:505-514

Rolff PMA (1946) Minerais dos pegmatitos da Borborema. DNPM Div Fom Prod Min Bol, vol. 78, pp 23-76, Rio de Janeiro

Roy PL, Dottin O, Madon HL (1964) Estudo dos pegmatitos do Rio Grande do Norte e da Paraíba. SUDENE Série Geol Econom 1:124

Scorza EP (1944) Província Pegmatítica da Borborema. DNPM, Div Geol Min Boletim vol. 112, p 57, Rio de Janeiro

Smeds S, Černý P, Chapman R (1999) Niobian calciotantite and plumboan-stannoan cesstibtantite from the island of Uto, Stockholm archipelago, Sweden. Can Mineral 37:665-672

Soares DR (2004) Contribuição à petrologia de pegmatitos mineralizados em elementos raros e elbaítas gemológicas da Província Pegmatítica da Borborema, NE-Brasil. Tese Dout. UFPE, p 271

Soares DR, Beurlen H, Ferreira ACM, Da Silva MRR (2007) Chemical composition of gahnite and degree of pegmatite fractionation in the Borborema Pegmatitic Province, Northeastern Brazil. An Acad Bras Ciên 79(3):1-10

Tavares JF (2001) Relatório de graduação do Curso de Engenharia de Minas. Unpubl. Final Report, Mining Engineering Undergraduate Course, UFPB (Federal University of Campina Grande-PB, Brazil), $44 \mathrm{pp}$

Tindle AG, Breaks FW (1998) Oxide minerals from the Separation Rapids rare-element granitic pegmatite group, Northwestern Ontario. Can Mineral 36:613-636

Tindle AG, Breaks FW (2000) Columbite-tantalite mineral chemistry from rare element granitic pegmatites: Separation Lake area, NW Ontario, Canada. Mineral Petrol 70:165-198

Tindle AG, Breaks FW, Webb PC (1998) Wodginite-group minerals from the Separation Rapids rare-element granitic pegmatite group, Northwestern Ontario. Can Mineral 36:637-658

Uher P, Broska I (1995) Pegmatites in two suites of Variscan orogenic granitic rocks. Mineral Petrol 55:127-136

Uher P, Černý P, Chapman R, Hatar J, Miko O (1998) Evolution of $\mathrm{Nb}$,Ta-oxide minerals in the Prasiva Granitic Pegmatites Slovakia. I. Primary Fe,Ti-rich assemblage. Can Mineral 36:525-534

Van Schmus WR, Brito Neves BB, Williams IS Hackspacher PC, Fetter AH, Dantas EL, Babinski M (2003) The Seridó Group of NE Brazil, a late Neoproterozoic pre- to syn-collisional basin in West Gondwana: insights from SHRIMP U-Pb detrital zircon ages and $\mathrm{Sm}-\mathrm{Nd}$ crustal residence $\left(\mathrm{T}_{\mathrm{DM}}\right)$ ages. Precambrian Res 127:287-327

Vlasov KA (1952) Texturelle und paragenetische Gliederung der Pegmatite. Mitt Akad Wiss USSR Geol Ser 2:30-55

Wirth R (2004) Focused ion beam (FIB): a nouvel technology for advanced application of micro- and nanoanalysis in geosciences and applied mineralogy. Eur J Mineral 16(6):863-876

Wise MA, Černý P, Falster AU (1998) Scandium substitution in columbite-group minerals and ixiolite. Can Mineral 36:673-680 